Primljeno: 2/11/2019

UDK: 373.3.091.312

Stručni rad

\title{
SURADNIČKO UČENJE U NASTAVI PRIMARNOGA OBRAZOVANJA
}

\section{Lidija Pecko}

OŠ „Dobriša Cesaric“, Požega

lidijapecko1@gmail.com 


\section{SAŽETAK}

U radu su predstavljeni rezultati ispitivanja stavova učitelja o primjeni suradničkoga učenja u nastavi primarnoga obrazovanja. Cilj je rada bio ispitati i utvrditi koliko često učitelji primjenjuju suradničko učenje u razrednoj nastavi i koliko se ova strategija učenja pokazala učinkovitom. Od metoda u radu je korištena metoda teorijske analize, od tehnika - tehnika anketiranja, a od instrumenata - anketni upitnik za učitelje konstruiran za namjere ovoga istraživanja. Rezultati istraživanja pokazuju da je suradničko učenje često primjenjivana strategija učenja u okviru svih nastavnih predmeta u nižim razredima osnovne škole. Učitelji najčešće tjedno i dnevno planiraju suradničko učenje u predmetima priroda i društvo te u hrvatskome jeziku, a mjesečno najčešće planiranju suradničko učenje iz likovne i glazbene kulture. Preporučuju ranije započeti sa suradničkim učenjem, bolje opremiti školu raznim pomagalima $i$ materijalima te uputiti i roditelje u odredene metode, tako da i oni mogu pridonijeti njihovu korištenju u ponavljanju i učenju nastavnoga sadržaja kod kuće.

Ključne riječi: osnovna škola, suradničko učenje, strategija, planiranje, razredna nastava. 


\section{UVOD}

Polazimo od spoznaje da različiti učenici uče na različite načine i da sadašnji modeli i vrste nastave ne omogućuju najvećem broju djece aktivno i kvalitetno stjecanje znanja. Strategije suradničkoga učenja su alternativa sadašnjemu tradicionalno predavačkom učenju, kroz koji učenik otkriva što sam mora naučiti, kako razviti osobne i komunikacijske vještine. Suradničko učenje kao način nastavnoga rada narušava tradicionalnu nastavu i školu (Jelavić, 1994, 102). Kod tradicionalnoga predavanja u razredu svaki se učenik mora izboriti za svojih pet minuta, pod uvjetom da to želi. Često se u velikim razredima događa kako učenik pasivno prati nastavu, a učitelj to ne primjećuje. Naravno, nije dovoljno da učenik bude samo prisutan, te da uči tek kada se najavi ispitivanje: učenik mora aktivno sudjelovati da bi znanje i vještine koje usvoji bile što kvalitetnije. Upravo suradnička nastava čini opis interakcijskih odnosa između subjekata odgojno-obrazovnoga procesa, odnosno nastavnika i učenika ili samo učenika. Ono je psihosocijalna pozadina cjelokupnoga odgojno-obrazovnoga rada.

Strategija dolazi od starogrčke riječi strategos i doslovno znači vođenje vojske. Pojam suradničko (kooperativno) učenje nastalo je kao antiteza na natjecateljsko (kompetitivno) učenje koje dominira u tradicionalnoj nastavi. Vremenom je izgubljeno to prvotno značenje i koristi se da bi se označilo postupanje usmjereno ka ostvarivanju određenoga cilja nakon dužega planiranja. Znači, stvoriti organizaciju razreda koja će poticati učeničke interakcije s ciljem međusobne suradnje. Temelji se na ideji da će učenici lakše otkriti, spoznati i razumjeti složene pojmove ako međusobno razgovaraju o onome što je predmet učenja (Kadum-Bošnjak, 2012)

\section{SURADNIČKO UČENJE}

Suradničko učenje uključuje zajedničko rješavanje problema, predlaganje i istraživanje dogovorenih tema te stvaranje novih ideja, novih kombinacija ili jedinstvene inovacije (Meredith i sur., 1998, prema Peko, Pintarić, 1999).

Ima autora koji su mišljenja da svaki skupni rad nije istovremeno i suradničko učenje, ali su svi jedinstvenoga stava da se suradničko učenje događa u skupini. Zapravo, suradničko učenje predstavlja zajednički rad učenika radi postizanja zajedničkih obrazovnih postignuća (Johnson, Johnson, 1989). Svaki učenik može postići svoj obrazovni cilj samo ako i cijela skupina postigne svoj. Zajednički grupni cilj motivira učenike da pomažu jedni drugima jer njegovo ostvarenje ovisi o udjelu svakoga člana. 
Osnovu suradničkoga učenja u grupnome radu čine:

- različitost razvojnih razina i znanja učenika

- razlike koje dovode do socijalno-kognitivnih konflikata, tj. do sukoba ideja čiji su nositelji različite ličnosti

- maksimalna motivacija za sudjelovanje u procesu učenja

- razlike u gledištima koje ukazuju na složenost i višedimenzionalnost pojave

- sukob ideja, koji je osnova dijaloga, rasprave i na taj način omogućava formiranje intelektualnih i komunikacijskih sposobnosti (Munjiza, Peko, Sablić, 2007, 42).

Brojna istraživanja pokazala su da učenicima koji na natjecanjima doživljavaju uspjeh, natjecanja postaju vrlo poticajna u učenju, međutim, onim učenicima koji u natjecateljskoj situaciji ne polučuju ili ne mogu polučiti uspjeh, bivaju destimulirajuća i ti učenici prije ili kasnije odustaju, te oni koji imaju priliku učiti na ovakav način, uče brže i lakše, a znanje im je dugotrajnije (duže se zadržava). Istraživanja prema Stoll i Finku (2000) naglašavaju kako je učenje djelotvornije unutar konteksta suradničkoga učenja i radnoga iskustva. Osim konvencionalnih temeljnih sposobnosti postoje i nove, primjerene svijetu u mijeni. Učenici će uspjeti u postmodernome svijetu ako posjeduju četiri skupa temeljnih sposobnosti:

- apstrakciju - sposobnost otkrivanja obrazaca i značenja

- sustavno razmišljanje - sposobnost uočavanja odnosa među pojavama

- eksperimentaciju - sposobnost nalaženja vlastitoga puta u trajnome učenju

- socijalne sposobnosti za suradnju s drugima (Reich, 1992, prema Stoll i Fink, 2000, prema Munjiza i dr., 2007, 43).

\section{OPĆE KARAKTERISTIKE SURADNIČKIH RAZREDA}

Johnson i Johnson (1989) smatraju kako se rezultati učenja poboljšavaju suradničkim učenjem. Da bi neka aktivnost bila suradnička, bitno je uključiti pet elemenata:

- pozitivnu međuovisnost - učenici uviđaju da su potrebni jedni drugima kako bi obavili neki zadatak, zato se i maksimalno trude, uzajamno pomažu i ne odustaju

- pojedinačnu i skupnu odgovornost - svaki učenik ima svoj zadatak, a njegov rezultat doprinosi i skupini

- osobna i izravna prijateljska interakcija - učenici komuniciraju, međusobno si pomažu, dogovaraju se, razmjenjuju i potiču učenje, prenose svoje znanje drugima, traže načine učenja

- socijalne vještine - skupine ne mogu dobro funkcionirati ako učenici ne raspolažu društvenim umijećima za suradnički rad kojim ih poučava uči- 
telj, a ona uključuju vodstvo, odlučivanje, izgradnju povjerenja, komunikaciju i upravljanje sukobom

- skupno procesiranje - članovi skupine raspravljaju o tome koliko su uspjeli ostvariti svoje ciljeve i održati djelotvorne odnose. Pojave li se poteškoće u odnosima, članovi se uključuju u identificiranje, definiranje i rješavanje problema (Bekavac, 2001).

Suradničko učenje, često se poistovjećuje s timskim radom u nastavi. Međutim, riječ je o dvama različitim oblicima rada u nastavi koji mogu imati zajednička obilježja. Za razliku od suradničkoga učenja koje smo definirali kao zajedničko učenje učenika u paru ili malim skupinama s ciljem rješavanja zajedničkih zadataka, proučavanja i istraživanja zajedničke teme ili nadogradnje uzajamne spoznaje radi stvaranja i razvijanja novih ideja, novih kombinacija ili jedinstvene inovacije, „timska nastava je zajednički stvaralački rad i odgovornost više učitelja i drugih suradnika na ostvarivanju programskih sadržaja u svim fazama nastavnoga rada s istim sastavom učenika različitih odjela u raznovrsnim oblicima odgojno-obrazovnog rada“ (Rosić, 2009, 32). Tako učenici u timu mogu surađivati, a suradničke skupine mogu funkcionirati kao timovi.

Suvremeno organizirana nastava mora brinuti o svim etapama odgojnoobrazovnoga procesa i najučinkovitijem vremenskom ustrojavanju nastavne djelatnosti kako bi se izbjegla jednoličnost rada i ostvarila zanimljivost i raznolikost u kojima do potpunoga izražaja može doći stvaralaštvo učitelja i naravno, učenika. Svjedoci smo brzih promjena u društvu, ogromnoga napretka znanosti i znanstvenih dostignuća, međutim, nastava je u školama ostala gotovo neizmijenjena, $\mathrm{u}$ velikoj je mjeri zastarjela, odnosno tradicionalna. Jedan od načina modernizacije nastave je primjena suradničkoga učenja. Upoznajući se s osnovnim karakteristikama suradničkoga učenja, lako se može uvidjeti i zaključiti da ovakav pristup nastavi može naći svoje mjesto u gotovo svim nastavnim predmetima. Od osobitoga je, naime, značaja da škola nauči učenike kako promatrati i promišljati jer učenik usvaja načine rada i putove stjecanja znanja.

Suradničko učenje vrlo je učinkovito kod etape ponavljanja i vježbanja nastavnih sadržaja i pritom učiteljima takav način rada ne predstavlja problem. Međutim, učiteljima poseban problem predstavlja kako suradničko učenje svrhovito rabiti pri obradi nastavnih sadržaja. Kako bi olakšao učiteljima, Jensen (2003) je izložio proces u deset koraka koji pruža jedinstveni plan za uspjeh suradničkoga učenja pri obradi nastavnih sadržaja. Koraci koji su sastavnica toga procesa jesu:

1. sadržaj - definirati cilj i zadatke nastavne jedinice te kod učenika izazvati znatiželju

2. bjašnjavanje zadatka - članovima (učenicima) suradničkih skupina treba objasniti zadatak, dati konkretne, učinkovite upute, te iznijeti svoja očekivanja 
3. sam „trenutak“ - provjeriti imaju li učenici pitanja te ih pustiti da razmišljaju o zadatku kako bi mogli doći do rješenja problema

4. usmjeriti na suradnju - učenike upućivati na suradnički odnos unutar skupine, ukazivati na važnost suradnje

5. započeti skupni rad - ne smije izostati pozitivan i logički poticaj, ali mora biti u granicama mogućega, $t$. intervencija učitelja mora biti minimalna

6. skupne izjave - izjave o tome kako proces u skupini može poboljšati i razviti školske i socijalne sposobnosti

7. učenici međusobno dijele školske i socijalne sposobnosti - učenici u razgovoru i interakciji s drugim učenicima članovima skupine iznose vlastita iskustva i osjećaje glede suradničkoga učenja i što su tijekom suradničkoga rada naučili

8. učitelj s učenicima dijeli školska i suradnička iskustva - učitelj upućuje učenicima svoja zapažanja o suradničkome učenju, ukazuje na njihovu suradnju i ponašanje tijekom zajedničkoga rada

9. zaključni razgovor i završetak - omogućiti učenicima da iznesu svoja iskustva vezana uz suradničko učenje te provjeriti individualnu odgovornost unutar skupine tijekom suradničkoga učenja

10. potrebno je čestitati učenicima uz pljesak - na uspješnome suradničkom učenju učenicima treba čestitati i poželjno je tu čestitku popratiti pljeskom (Kadum-Bošnjak, 2012, 188).

\section{PREDNOSTI SURADNIČKOGA UČENJA}

Čudina-Obradović i Težak (1995) za dvije temeljne prednosti suradničkoga učenja navode: pomaže razvijanju sposobnosti rješavanja problema i sposobnosti zaključivanja te poboljšava odnose medu članovima skupine i vlastito samopoštovanje.

Suradničkim učenjem poboljšavaju se rezultati učenja (Peko, Pintarić, 1999). Merediht, Steele i Temple (prema Peko, Pintarić, 1999) navode rezultate sudjelovanja u suradničkome učenju: bolji uspjeh i produljeno pamćenje, češće razmišljanje višega reda, dublje razumijevanje i kritičko mišljenje, usredotočeniji rad u razredu i manje nediscipline, veća motiviranost za bolje ocjene i učenje, veća sposobnost da se situacija promotri iz tuđe perspektive, veća društvena podrška, pozitivniji, tolerantniji i prijateljskiji odnosi s vršnjacima bez obzira na etničku ili spolnu pripadnost, prirodne sposobnosti, stalež ili druge razlike, pozitivniji odnos prema samome sebi na temelju samoprihvaćanja, povećanje uvida u vlastito ponašanje, smanjivanje snažnih duševnih smetnji poput zakočenosti, nervoze, depresije, straha, veće društvene kompetencije, pozitivniji stavovi prema predmetima, učenju i školi, pozitivniji odnos prema učiteljima, ravnateljima i ostalom školskom osoblju (Kadum-Bošnjak, 2012). 
Noviji pristupi učenju i nastavi potiču prilagodbu procesa učenja osobinama učenika i stilu njegova učenja i mišljenja. Dokazano je da suradničko učenje pridonosi učinkovitijem usvajanju znanja i vještina u različitim područjima, od matematike do društvenih znanosti (Hansman i sur., 1999, Klarin, 1998, prema Cota-Bekavac i sur., 2003), potiče najmanje motivirane i neuspješne učenike, potiče razvoj kritičkoga, kreativnoga i logičkoga mišljenja (Meredith i sur., 1998, prema Peko, Pintarić, 1999), povećava motivaciju i ustrajnost učenika u učenju, potiče bolje odnose među učenicima, ne samo u radu nego i u drugim situacijama (Johnson, Johnson, 1998), unaprjeđuje različite socijalne vještine, jača samopouzdanje i samopoštovanje učenika (Arends, 1991, prema Cota-Bekavac i sur., 2003), a osobito je prikladno za uključivanje djece s teškoćama u razvoju (Gillies, Ashman, 2000). Okruženje koje omogućuje neposredne kontakte, ravnopravan položaj svih sudionika te javno odobravanje međuetničke suradnje, utječe na smanjenje međurasnih predrasuda (Allport, prema Cota-Bekavac i sur., 2002, prema Munjiza i sur., 2007, 44). Pozitivni ishodi raznih suradničkih strategija, potakli su i niz istraživanja usredotočenih na sprječavanje niza društvenih problema, delikvencije, uporabe droga, maloljetničkoga školskog nasilja, rasizma, seksizma, isključivanja tjelesno oštećenih, egocentrizma, manjka društvenih vještina.

\section{SURADNIČKO UČENJE I ULOGA UČITELJA}

Aktivno stjecanje znanja i kreiranje stvaralačkoga rada učenika u pozitivnome razrednom ozračju u središtu je zahtjeva suvremene škole. Zahtjevi se odražavaju i u zahtjevima za izmjenama uloge učitelja. Učitelj pak treba dobro poznavati organizacijsku strukturu problemske nastave kako bi unaprijedio svoj rad. Jedan od bitnih zadataka je poticanje učenika na istraživanje, upozoravanje na istraživanje, više nego na učinke istraživanja. Inovativni učitelj stvara inovativni razred. U takvome razredu izražena je kvaliteta i uspješnost. Učitelj ili razrednik nije samo predavač svoga predmeta nego i odgojitelj, on je nositelj cjelokupne odgojno-obrazovne djelatnosti u školi. „O njemu, njegovu obrazovanju i sposobnostima, njegovu moralnom liku, odnosu prema radu, materijalnim i duhovnim vrednotama ovisni su rezultati i uspjeh te djelatnosti“(Vukasović, 1998, 239).

Učenici postaju zahtjevniji. „Njihova najčešća pritužba glasi da je nastava predosadna“ (Meyer, 2002, 23). U kreiranju suradničke nastave učitelj motivira učenika, nastojeći pobuditi u njemu znatiželju za novim spoznajama. Uvodi nove i spektakularnije sadržaje, oblike rada i uvijek razmišlja o najboljoj metodi kojom će potaknuti učenike. „Nije važno samo ono što zna nastavnik; isto je toliko važan način kojim on pomaže učeniku da zna znati“ (Barth, 2004, 17). Učiteljev posao, 
ne temelji se samo na prijenosu znanja; on uključuje i prezentaciju toga znanja u obliku zadavanja problema unutar određenoga konteksta i stavljanja problema u određeni odnos, kako bi učenik povezao njihovo rješenje sa širim pitanjima. Nakon toga učenik sam radi na upoznavanju problema, ali nastavnik ostaje izvor odgovora na pitanja koja postavljaju učenici o problemu. To je najvažniji preduvjet za potpuni uspjeh procesa učenja. Uz to, u modernim društvima postaje iznimno važno poučavati kako pomoći pojedincu stvarati osobne sudove i razviti osjećaj osobne odgovornosti te tako omogućiti učenicima razviti sposobnost predviđanja promjena i prilagodbe istima, drugim riječima nastaviti učiti cijeli život. „Ako učenik ne nauči tako da može upotrijebiti svoje znanje, kao što to čini stručnjak, kako bi percipirao i tumačio određenu stvarnost, na svojoj razini, kako bi raspravljao i debatirao s drugima, za opravdanje svojih postupaka, tada je to znanje osuđeno ostati nataloženo znanje, beskorisno, osim možda za polaganje ispita" (Barth, 2004, 17).

Postavke o važnosti iskustvenoga, aktivnoga učenja koje mijenja ulogu učenika kao pasivnoga slušatelja kojima dominira učitelj, također su znatno pridonijele razvoju modela suradničkoga učenja kao sredstva da se kod učenika potiče aktivno stvaranje vlastitoga razumijevanja, razvoj različitih razina mišljenja i komunikacijskih i socijalnih vještina (Ardens, 1991).

Medu znanstvenicima koji su se bavili kooperativnim učenjem razvile su se brojne strategije koje je moguće primijeniti u različitim nastavnim predmetima i u okviru različitih etapa nastave. Neke od tehnika su:

- insert metoda

- slagalica

- dvostruki dnevnik

- predviđanje u paru

- razmisli (izmijeni) u paru

- osmisli, razmijeni, poslušaj, stvori

- kolo naokolo

- misaoni mozaik - oluja ideja

- umne mape

- stablo budućnosti

- igra uloga

- kockarenje. 


\section{STRATEGIJE SURADNIČKOGA UČENJA}

Insert metodom učenici aktivno prate svoje čitanje i razumijevanje pročitanoga. Pojedine dijelove teksta označavaju dogovorenim znakovima: + nove informacije, $\sqrt{ }$ poznato od prije, ? nepoznato, nejasno.

Slagalica - suradnička struktura slagalice je u tome da članovi neke suradničke skupine postanu stručnjaci u određenome polju neke nastavne teme. Razred je podijeljen u grupe, tzv. matične skupine. Tema koja se proučava podijeljena je na četiri dijela. Unutar matične skupine učenici su podijeljeni, na primjer, brojevima - jedinice, dvojke, trojke, četvorke. Svaki učenik dobije neki dio teksta i svi oni učenici kojima je dodijeljen jednak broj premještaju se i čine ekspertnu skupinu, koji zajedno rade na istome dijelu teksta i postaju eksperti iz toga dijela. Ekspertna skupina proučava svoj dio teksta i planira učinkovite načine za poučavanje važnim informacijama u svojim matičnim skupinama kada se vrate u njih. Po završetku učenici se vraćaju iz ekspertnih skupina u matične skupine i poučavaju ostale učenike sadržaju. Članovi matičnih skupina trebali bi zapisivati sva pitanja koja su u doticaju s bilo kojim dijelom teksta. Ta bi pitanja trebalo uputiti grupnom ekspertu koji je odgovoran za taj dio.

Tehnikom dvostrukoga dnevnika potiče se učenike čitati promišljeno i pozorno, te pročitano povezati sa sobom i s pitanjima koja ih zanimaju. Tehnika je korisna kad učenici moraju kod kuće pročitati neki duži tekst. Koristi se kod stručnih i proznih tekstova kao aktivnost u fazi razumijevanja značenja i refleksije.

Predviđanje u paru je tehnika vođenoga čitanja koja potiče učenike na pozorno čitanje teksta provjeravajući svoja predviđanja u dijelovima teksta. Uspoređivanje osobnih predviđanja u tekstu i onoga što je stvarno napisano u tekstu, povećava njihov interes za čitanjem teksta, ali pridonosi i razumijevanju i provjeri vlastitoga razumijevanja. Učenici se podijele u parove. Na ploči napišemo popis riječi koji se odnose na likove, okruženje i dio priče. Zamolimo parove učenika neka porazgovaraju o čemu bi mogla govoriti priča i da svoja predviđanja u vezi nje zapišu. Nakon toga se čita priča u cjelini tijekom čega učenici mogu pratiti jesu li što uspjeli predvidjeti.

Razmisli (izmijeni) u paru je strategija brze aktivnosti suradničkoga učenja koja od učenika traži razmišljanje o tekstu te da im kolege pomažu u oblikovanju ideja. Može se ponavljati nekoliko puta tijekom čitanja ili predavanja. Na pitanja koja je učitelj pripremio unaprijed učenici daju svoj odgovor koji uključuje ideje u paru. Ova strategija omogućuje učenicima sigurnost i potvrdu svoga odgovora ili ideje. Kada učenik sam riješi zadatak ili ako nije siguran, dobro će mu doći i pomoći će mu da u radu s drugim učenikom dođe do rješenja, otkloni netočnost ili potvrdi svoj odgovor. 
Kolo naokolo suradnička je aktivnost u kojoj se jedan papir i olovka sustavno šalju od člana do člana skupine. Jedan sudionik zapiše neku ideju i pošalje papir i olovku učeniku s lijeve strane (naravno, ne nužno; papir i olovka mogu krenuti i udesno). Taj učenik već zapisanoj ideji dopiše nešto svoje i pošalje papir dalje. Postoji i usmena inačica ove tehnike suradničkoga učenja. Pritom svaki član grupe usmeno priopćava svoju ideju na kružan način.

Oluja ideja, odnosno brainstorming, tehnika je kreativnoga mišljenja kojoj se nabrajaju i zapisuju rješenja nekoga problema, a služi za stvaranje velikoga broja ideja. Svaki učenik u skupini mora se truditi da dâ što više prijedloga koji se ne kritiziraju i ne odbacuju, bez obzira koliko su dobri, razumni i izvedivi. Tek u kasnijim fazama provodi se raščlamba svakoga odgovora, odbacivanje neprihvatljivih i zadržavanje dobrih ideja. Osnivač ove metode A. Ozborn, oluju ideja definira kao metodu kojom grupa ljudi pokušava naći rješenje za određeni problem tako što sastavlja listu spontano nastalih ideja. Svoju primjenu našla je i u školi/obrazovanju: koristi se, na primjer, u edukativnim i kreativnim radionicama pri izradi grupnih projekata, ali može biti vrlo učinkovita i u individualnome radu. Oluja ideja prikladna je za generiranje novih, originalnih i neobičnih ideja. Osnovna postavka zasniva se na tome da pojedinci s različitim iskustvima i znanjima drugačije pristupaju problemu, kao i da se ideje hrane drugim idejama. Pritom svaka oluja ideja mora započeti nekim konkretnim pitanjem. Cilj je potom iznijeti što je više moguće ideja, bez ikakve cenzure i vrednovanja; prve ideje su vrlo često klišei. Svaka ideja je dobro došla, ma koliko djelovala nepravilno - ponekad se pokaže da upravo takve ideje budu najkorisnije. Ideje ne treba obrazlagati, objašnjavati niti braniti jer u ovoj fazi svaka kritika, neodobravanje ili primjedba nije dozvoljena.

Umne mape strategija su koja potiče učenike otvoreno razmišljati o nekome pojmu. Može se primijeniti u bilo kojoj etapi nastavnoga sata. U sredini papira napiše se ključni pojam. Učenicima se ostavi nekoliko minuta vremena kako bi napisali sve što im padne na pamet $u$ vezi s ključnim pojmom. Zatim se crtama spoje pojmovi koji su u nekakvoj vezi te se dopišu još neki pojmovi kojih se učenici mogu prisjetiti tijekom pisanja. Steele i sur. (2003, prema Kadum-Bošnjak, 2013) ističu kako mentalne mape predstavljaju fleksibilnu strategiju. Mogu se oblikovati individualno ili grupno. Kao grupna aktivnost mogu poslužiti kao polazište za grupne ideje, što omogućuje učenicima dodir s asocijacijama i vezama koje su drugi učenici izvukli iz primjera.

Stablo budućnosti suradnička je metoda učenja s mnogo inačica. Svaki učenik na zajedničkome stablu ima svoju granu na koju se kasnije dodaju listovi i/ili cvjetovi na kojima se pišu ideje, prijedlozi ili raščlanjuje neki aktualni 
problem, posljedice toga problema i rješenje. Ova se metoda može kombinirati s olujom ideja.

Igra uloga jedna je od strategija koja se koristi kod skupnoga rada. Uloge koje učenici glume mogu biti u svrhu održavanja skupine, rješenja zadataka ili oboje.

Kockarenje omogućuje promatranje teme iz različitih kutova. Na svaku plohu kocke napiše se zadatak koji od učenika zahtijeva analizu, promišljanje, vrednovanje, povezivanje, vrednovanje obrađenih sadržaja. Zadaci na kocki mogu biti: opiši, usporedi, poveži s, raščlani, primijeni, za/protiv.

\section{METODA}

U radu je korištena metoda teorijske analize, od tehnika - tehnika anketiranja.

\section{Predmet}

Predmet istraživanja je istražiti, ispitati i utvrditi koliko je suradničko učenje zastupljeno u nastavnome radu medu učiteljima razredne nastave u osnovnoj školi.

\section{Cilj istraživanja}

Cilj je istraživanja ispitati i utvrditi koliko često učitelji primjenjuju suradničko učenje u razrednoj nastavi i koliko se ova strategija učenja pokazala uspješnom i efikasnom.

\section{Zadaci istraživanja}

Iz navedenoga predmeta i cilja istraživanja proizlaze zadaci istraživanja:

- ispitati i utvrditi na kojim nastavnim predmetima učitelji najčešće primjenjuju suradničko učenje

- ispitati i utvrditi kojim se strategijama suradničkoga učenja učitelji najčešće koriste u radu s učenicima

- ispitati i utvrditi u kom nastavnom predmetu se suradničkim učenjem postižu najefikasniji rezultati i u okviru kojih strategija

- ispitati i utvrditi koje su prednosti suradničkoga učenja u odnosu na tradicionalnu nastavu, a koja su ograničenja za njegovu primjenu

- ispitati i utvrditi kako učenici i njihovi roditelji prihvaćaju suradničko učenje

- ispitati i utvrditi imaju li učitelji primjerenu podršku u implementaciji interaktivnoga učenja

- ispitati koje mjere učitelji predlažu u cilju unaprjeđenja suradničkoga učenja u našoj nastavnoj praksi. 


\section{Hipoteze}

U istraživanju smo pošli od pretpostavke da je suradničko učenje često zastupljena strategija učenja u našim školama u razrednoj nastavi zbog njegovih prednosti.

\section{Pomoćne hipoteze}

Na osnovu glavne hipoteze postavili smo sljedeće pomoćne hipoteze:

- Pretpostavlja se da učitelji u svome radu u nastavi primjenjuju suradničko učenje u okviru različitih nastavnih predmeta.

- Pretpostavlja se da učitelji primjenjuju i koriste se u svome radu u nastavi različitim strategijama suradničkoga učenja.

- Pretpostavlja se da suradničko učenje daje različite učinke u okviru pojedinih nastavnih predmeta, ovisno o strategiji.

- Pretpostavlja se da su brojne prednosti, ali i ograničenja u našim školama, koje uzrokuje primjena suradničkoga učenja.

- Pretpostavlja se da učenici rado prihvaćaju različite strategije suradničkoga učenja i da su roditelji zadovoljni njihovom primjenom.

- Pretpostavlja se da učiteljima nedostaje adekvatna podrška u primjeni suradničkoga učenja.

- Pretpostavlja se da će učitelji predložiti brojne mjere u cilju unaprjeđenja suradničkoga učenja u našim školama.

\section{Mjerni instrument}

U radu je korišten anketni upitnik za učitelje konstruiran za namjere ovoga istraživanja.

\section{Uzorak}

Ispitanici su bili učitelji razredne nastave gradskih škola Požege, šk. god. 2018./2019. Sudjelovalo je 65 učitelja: Osnovne škole „Dobriša Cesarić“, Požega; Osnovne škole Julije Kempf, Požega; Osnovne škole Antun Kanižlić, Požega i Osnovne Katoličke škole, Požega. 


\section{REZULTATI I RASPRAVA}

Na osnovi analize došli smo do sljedećih rezultata:

odgovori na pitanje u kojim nastavnim predmetima učitelji najčešće planiraju suradničko učenje vidljivo je iz Grafa 1.

\section{Graf 1: Planiranje suradničkoga učenja u nastavnim predmetima}

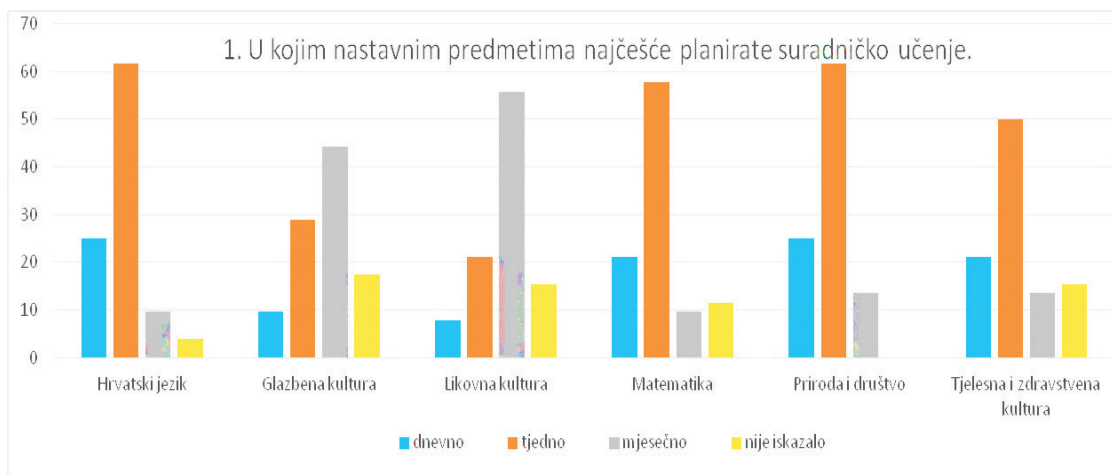

Iz grafa vidimo da učitelji planiraju suradničko učenje u svim nastavnim predmetima. Najčešće planiraju tjedno, i to u predmetima priroda i društvo te u hrvatskome jeziku $61,53 \%$. Slijedi ih matematika s $57.6 \%$, tjelesna i zdravstvena kultura s $50 \%$, a najrjeđe tjedno planiraju suradničko učenje iz glazbene kulture $28.8 \%$ te likovne kulture $21.15 \%$.

Pri dnevnome planiranju suradničko učenje je najčešće u prirodi i društvu te hrvatskome jeziku $25 \%$, dok se dnevno najmanje planira suradničko učenje iz likovne kulture $7.6 \%$.

U mjesečnome planiranju učitelji najčešće planiraju suradničko učenje iz likovne kulture $55.7 \%$, slijedi glazbena kultura $44.2 \%$, a najmanje mjesečno planiraju suradničko učenje iz hrvatskoga jezika i matematike $9.6 \%$.

Pitali smo ispitanike koje strategije suradničkoga učenja planiraju u svome radu te da vremenski odrede koliko dnevno, tjedno i mjesečno (Graf 2.). 
Graf 2.: Strategije suradničkoga učenja u radu, dnevno, tjedno i mjesečno

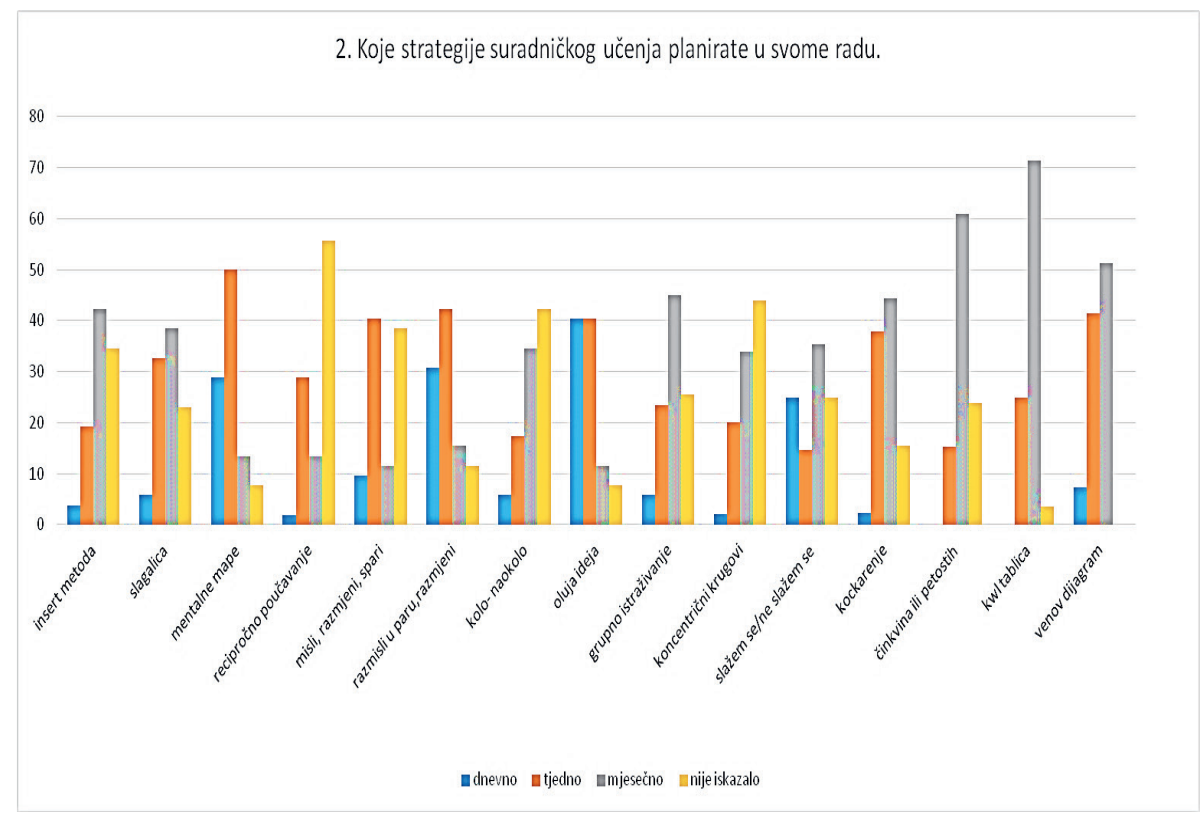

Iz grafa je vidljivo da ispitanici poznaju velik broj strategija suradničkoga učenja i da ih sve rabe u radu u nastavi. Najčešće korištene strategije, tj. strategije koje dnevno najčešće koriste su oluja ideja $40.3 \%$, mentalne mape $28.8 \%$, a uopće dnevno ne rabe činkvinu ili petostih i tablicu kwl (0 \%).

Strategije koje tjedno najčešće koriste su razmisli u paru, razmijeni $42.3 \%$, oluja ideja $40.3 \%$, misli, razmijeni, spari $40.3 \%$, a najmanje se tjedno koriste strategijom slažem se / ne slažem se $14.58 \%$, činkvinom ili petostihom $15.2 \%$.

Strategije kojima se mjesečno najčešće koriste su kwl tablica $71.4 \%$, činkvina ili petostih $60.8 \%$, a najmanje se mjesečno koriste strategijom oluja ideja $11.5 \%$ te misli, razmijeni, spari $11.5 \%$.

Ispitali smo učitelje u kojim se nastavnim predmetima suradničkim učenjem postižu najefikasniji rezultati u postizanju obrazovnih postignuća, te da naznače koliko često (Graf 3.). 
Graf 3.: Najefikasniji rezultati u postizanju obrazovnih postignuća

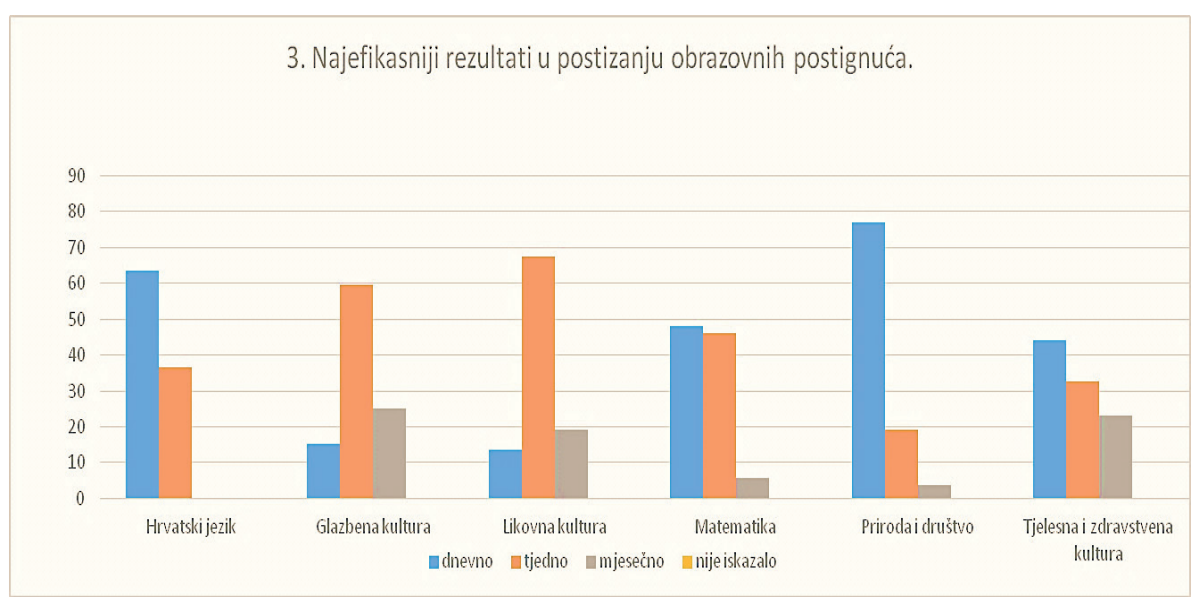

Iz grafa je vidljivo kako učitelji smatraju da suradničkim učenjem postižemo najefikasnije rezultate $u$ postizanju obrazovnih postignuća i to najčešće u nastavi prirode i društva $72.9 \%$, hrvatskoga jezika $63.4 \%$ i matematike $48.07 \%$. Ponekad u likovnoj kulturi $67.3 \%$, 25 \% učitelja smatra da se suradničkim učenje nikad ne postiže najefikasnije rezultate u nastavi glazbene kulture.

Ispitali smo učitelje koje su najefikasnije strategije suradničkoga učenja u postizanju obrazovnih postignuća učenika (Graf 4.). 
Graf 4.: Najefikasnije strategije suradničkoga učenja u postizanju obrazovnih postignuća učenika

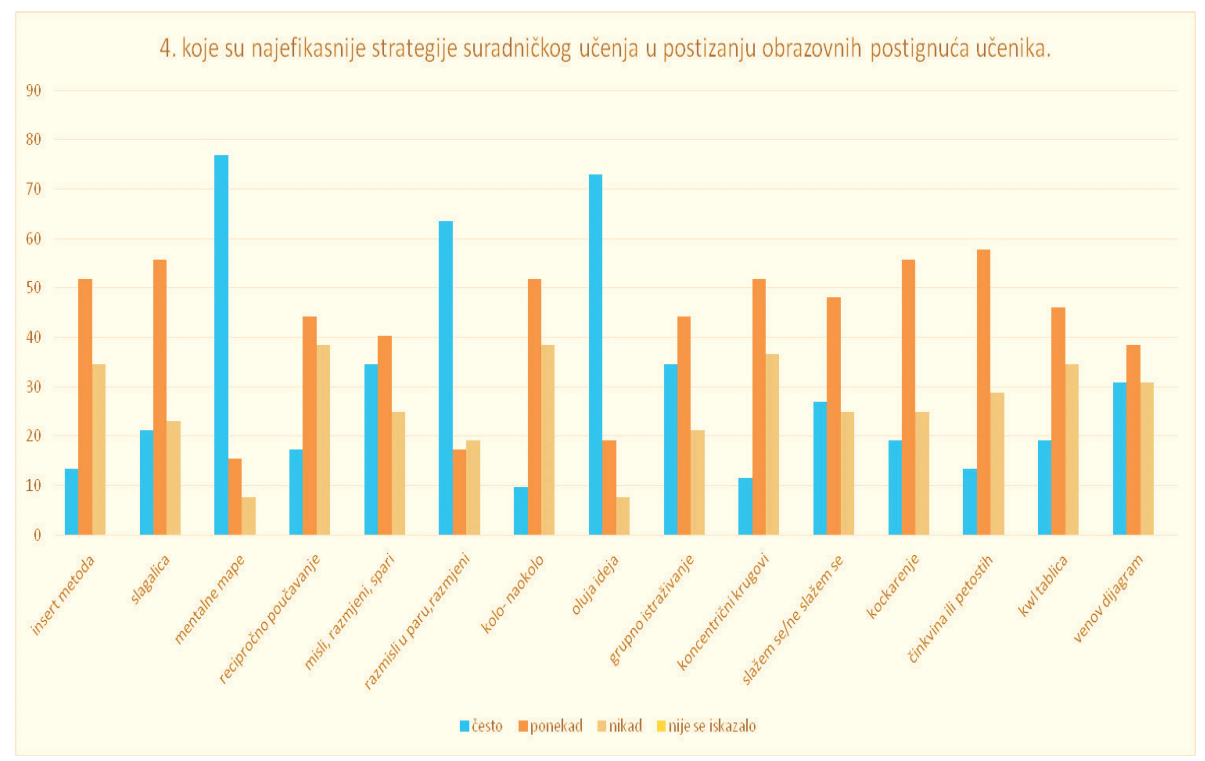

Iz priloga je vidljivo da učitelji smatraju kako su najefikasnije strategije suradničkoga učenja u postizanju obrazovnih postignuća mentalne mape $76.9 \%$, oluja ideja $73.0 \%$, razmisli u paru, razmijeni $63.4 \%$.

Ponekad su najefikasnije strategije suradničkoga učenja u postizanju obrazovnih postignuća učenika, činkvina ili petostih $57.6 \%$, slagalica $55.7 \%$ i kockarenje $55.7 \%$.

Ispitanici smatraju da strategije suradničkoga učenja u postizanju obrazovnih postignuća nikad nisu efikasne recipročno poučavanje $38,4 \%$, kolo naokolo $38.4 \%$ i koncentrični krugovi $36.5 \%$.

U anketnome ispitivanju smo tražili da učitelji navedu prednosti suradničkoga učenja. Odgovori su bili:

- samostalnost

- mogućnost natjecanja

- suradnja

- lakše i brže razumijevanje nastavnoga sadržaja

- zanimljivost

- mogućnost da se djeca bolje upoznaju

- mogućnost da učenici pomažu jedni drugima

- svaki učenik može doprinijeti svojim znanjem uspjehu grupe

- razmjena iskustva 
- uče slušati jedni druge te nadopunjuju svoje znanje slušanjem drugih

- razvoj samopouzdanja

- učenici vole uloge

- učenici prihvaćaju uloge i odgovornost za rezultat skupine

- trajnije je znanje

- učenici vole različite metode suradničkoga učenja, potiču ih na ravnopravnost, toleranciju

- poticanje kreativnoga mišljenja

- zabava, druženje.

Na pitanje koji su nedostaci suradničkoga učenja, ispitanici su odgovorili:

- učenici nisu koncentrirani

- učenici su bez samokontrole

- vremenski je nemoguće ostvariti sve zadane pojmove, a i neki učenici su zapostavljeni

- neravnopravnost sudjelovanja u radu

- slabiji učenici ne surađuju

- uvijek netko izbjegne aktivnost $\mathrm{i}$,šlepa“ se uz nekoga

- različiti interesi učenika i predznanja

- različita motivacija i sposobnost učenika

- uvijek se ističu bolji učenici

- potrebno je dosta organiziranja, za neke i dodatnoga materijala

- nepotpuno usvajanje pojmova i obrazovnih postignuća

- buka i žamor u razredu

- nema nedostataka, osim u tehničkoj izvedbi.

Pitali smo tko pruža podršku u cilju primjerene implementacije suradničkoga učenja (Graf 5.). 
Graf 5.: Pružanje podrške u cilju primjerene implementacije suradničkoga učenja

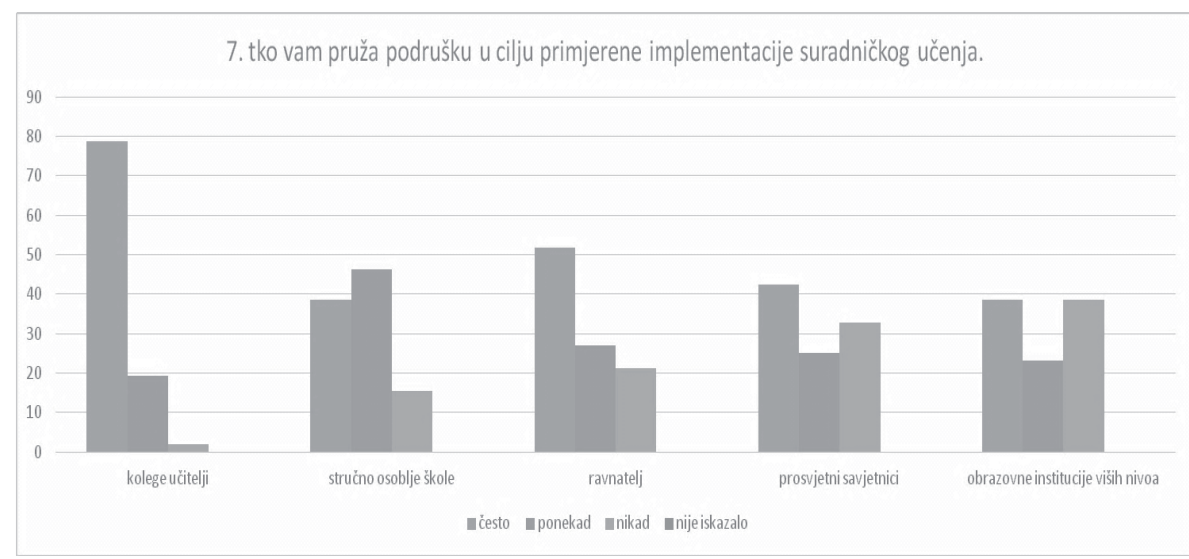

Iz grafa je vidljivo da učiteljima najčešće pružaju podršku kolege učitelji 78.8 $\%$, ravnatelj $51.9 \%$, prosvjetni savjetnici. Ponekad podršku pruža stručno osoblje škole $46.15 \%$, a nikad obrazovne institucije viših nivoa $38.4 \%$.

$\mathrm{U}$ anketnome ispitivanju učitelji su naveli nekoliko prijedloga kojim bi unaprijedili suradničko učenje u nastavnome radu. To su:

- - više literature o suradničkome učenju i konkretnih primjera

- - smanjiti nastavne sadržaje i administraciju učitelja, dati im više slobode i vremenskoga prostora

- - što ranije započeti s učenicima suradničko učenje

- - više praktičnih primjera

- - bolja opremljenost škole raznim pomagalima i materijalima

- - uputiti i roditelje u određene metode, tako da i oni mogu pridonijeti njihovim korištenjem u ponavljanju i učenju nastavnoga sadržaja kod kuće.

\section{ZAKLJUČCI}

Modernizacija nastave bitna je u današnjem školskom sustavu, od nastavnih sredstava i pomagala, digitalizacije, do izmjene rada u nastavi. Bit je postići da učenik bude aktivan, a ne pasivan promatrač. Strategije suradničkoga učenja omogućuju aktivno i kvalitetno stjecanje znanja. Na taj način, učenik stvara nove ideje, sudjeluje u zajedničkoj raspravi skupine, kombinira i formira svoje postojeće znanje, nadograđuje ga. Rezultati učenja, poboljšavaju se suradničkim učenjem, razvijaju se sposobnosti rješavanja problema, sposobnosti zaključivanja. Poboljšavaju se odnosi među članovima skupine i vlastitoga samopoštovanja. Potiču se najmanje motivirani i neuspješni učenici. 
Strategije suradničkoga učenja insert metoda, slagalica, dvostruki dnevnik, predviđanje u paru, razmisli (izmijeni) u paru; osmisli, razmijeni, poslušaj, stvori; kolo naokolo; misaoni mozaik - oluja ideja; umne mape; stablo budućnosti; igra uloga; kockarenje predstavljaju strategije najčešće korištene u radu ispitanih učitelja.

U radu je korišten anketni upitnik za učitelje, konstruiran za namjere ovoga istraživanja. Predmet istraživanja je istražiti, ispitati i utvrditi koliko je suradničko učenje zastupljeno u nastavnome radu među učiteljima razredne nastave $\mathrm{u}$ osnovnoj školi. Cilj je istraživanja ispitati i utvrditi koliko često učitelji primjenjuju suradničko učenje u razrednoj nastavi i koliko se ova strategija učenja pokazala uspješnom i efikasnom. U istraživanju smo pošli od pretpostavke da je suradničko učenje često zastupljena strategija učenja u našim školama u razrednoj nastavi zbog njegovih prednosti. Ispitanici su bili učitelji razredne nastave šk. god. 2018./2019. iz Požege i to iz OŠ „Dobriša Cesarić“, OŠ Julije Kempf, OŠ Antuna Kanižlića i Osnovne Katoličke škole.

$\mathrm{Na}$ osnovi analize rezultata došli smo do zaključka da učitelji planiraju suradničko učenje u svim nastavnim predmetima razredne nastave. Najčešće planiraju tjedno, i to u predmetima priroda i društvo te u hrvatskome jeziku, a najrjeđe tjedno planiraju suradničko učenje iz glazbene kulture te likovne kulture. Dnevno planiranju suradničko učenje najčešće u nastavi prirode i društva te hrvatskoga jezika. Mjesečno planiranju najčešće suradničko učenje iz likovne i glazbene kulture.

Ispitanici poznaju velik broj strategija suradničkoga učenja i svima se koriste u radu u nastavi. Najčešće korištene strategije, tj. strategije kojima se dnevno najčešće koriste su oluja ideja, mentalne mape, tjedno se najčešće koriste strategijama razmisli u paru, razmijeni, oluja ideja, misli, razmijeni, spari, a mjesečno najčešće strategijama kwl tablica, činkvina ili petostih.

Učitelji smatraju kako suradničkim učenjem postižemo najefikasnije rezultate u postizanju obrazovna postignuća i to najčešće u nastavi prirode i društva, hrvatskoga jezika i matematike. Ponekad u likovnoj kulturi, a nikad u nastavi glazbene kulture.

Najefikasnije strategije suradničkoga učenja u postizanju obrazovnih postignuća su mentalne mape, oluja ideja, razmisli u paru, razmijeni. Ponekad su najefikasnije strategije suradničkoga učenja u postizanju obrazovnih postignuća učenika, činkvina ili petostih, slagalica i kockarenje. Strategije suradničkoga učenja koje nisu efikasne u postizanju obrazovnih postignuća su recipročno poučavanje, kolo naokolo i koncentrični krugovi.

Prema mišljenju učitelja, prednosti suradničkoga učenja su veća samostalnost, mogućnost natjecanja, suradnja, lakše i brže razumijevanje nastavnoga sa- 
držaja, zanimljivost, svaki učenik može doprinijeti svojim znanjem uspjehu grupe, razvoj samopouzdanja i trajnije je znanje stečeno strategijama suradničkoga učenja. Ispitanici smatraju da je nedostatak suradničkoga učenja ograničeno vrijeme u kojem je nemoguće ostvariti sve zadane pojmove, a i neki su učenici zapostavljeni. Potrebno je dosta organiziranja, a za neke i dodatnoga materijala te se nepotpuno usvajaju pojmovi i obrazovna postignuća pa je nakon takvoga sata potrebno dosta ponavljanja i uvježbavanja. Pri primjeni strategija nastaje buka i žamor u razredu.

Učiteljima najčešće pružaju podršku kolege učitelji, ravnatelj, prosvjetni savjetnici. Ponekad podršku pruža stručno osoblje škole, a nikad obrazovne institucije viših nivoa.

Učitelji bi unaprijedili suradničko učenje u nastavnome radu upoznavanjem više literature o suradničkome učenju i konkretnim primjerima. Smanjili bi nastavne sadržaje i administraciju učitelja, a iskoristili veću slobodu i vrijeme. Preporučuju ranije započeti s učenicima suradničko učenje, bolje opremiti školu raznim pomagalima i materijalima te uputiti i roditelje u određene metode, tako da i oni mogu pridonijeti njihovim korištenjem u ponavljanju i učenju nastavnoga sadržaja kod kuće. 


\section{LITERATURA}

1. Arends, R. I. (1991). Learning to teach. New York: McGraw-Hill.

2. Barth, B. M. (2004). Razumjeti što djeca razumiju, Struktura znanja i njegovo oblikovanje, Problemi prijenosa znanja. Zagreb: Profil.

3. Cota Bekavac, M. (2002). Istraživanja suradničkog učenja. Napredak, 143 (1): 32-40.

4. Cota Bekavac, M. (2001). Usavršavanje kritičkog mišljenja i komunikacijskih vještina edukativnom raspravom (debatom). Suvremena psihologija, 4 (1-2): 212-131.

5. Čudina-Obradović, M., Težak, D (1995). Mirotvorni razred: priručnik za učitelje o mirotvornom odgoju. Zagreb: Znamen.

6. Gillies, R. M., Ashman, A. F. (2000). The Effects of Cooperative Learning on Students with Learning Difficulties in the Lower Elementary School, Journal of Special Education, 34(1): 19-27.

7. Jelavić, F. (1994). Didaktičke osnove nastave. Jastrebarsko: Slap.

8. Jensen, E. (2003). Super-nastava. Nastavne strategije za kvalitetnu školu i uspješno poučavanje. Zagreb: Educa.

9. Johnson, D., Johnson, R. (1989). Cooperation and competition. Edina, MN: Interaction.

10. Meyer, H. (2002). Didaktika razredne kvake, rasprave o didaktici, metodici i razvoju škole. Zareb: Educa.

11. Munjiza, E., Peko, A., Sablić, M. (2007). Projektno učenje. Osijek: Fakultet za odgojne i obrazovane znanosti.

12. Kadum-Bošnjak, S. (2012). Suradničko učenje, Metodički ogledi: časopis za filozofiju odgoja, 19 (1): 181-199.

13. Peko, A., Pintarić, A. (1999). Uvod u didaktiku hrvatskoga jezika. Osijek: Pedagoški fakultet. Sveučilište J. J. Strossmayera.

14. Rosić, V. (2009). Timski rad/timska nastava. Pula: Visoka tehnička škola u Puli - Politehnički studij.

15. Stoll, L., Fink, D. (2000). Mijenjajmo naše škole, Kako unaprijediti djelotvornost i kvalitetu škola, Zagreb: Educa.

16. Temple, C., Meredith, K., Steele, J. L. (1997). How children learn: A statement of first principles. Geneva, NJ: Reading \& Writing for Critical Thinking Project.

17. Vukasović, A. (1998). Pedagogija. Zagreb: Hrvatski katolički zbor Mi. 


\title{
COLLABORATIVE LEARNING IN PRIMARY EDUCATION TEACHING
}

\begin{abstract}
This paper presents the results of examining teachers' attitudes towards the application of collaborative learning in primary education teaching. The aim of the paper was to examine and determine how often the teachers use collaborative learning in primary education teaching and how efficient this teaching strategy is. The research used the theoretical analysis method, the survey technique and a questionnaire for the teachers, constructed for the purposes of this research. The results of the research show that collaborative learning is frequently used as a teaching strategy in all school subjects in the lower grades of primary education. The teachers mostly plan collaborative learning weakly and daily in the subjects of science and Croatian language, while they plan it monthly in art and music subject. They recommend starting early with the collaborative learning, equipping the school with various tools and materials as well as referring the parents to certain collaborative learning methods. This way, they can also contribute to the use of those methods in reviewing and learning the teaching content at home.
\end{abstract}

Key words: primary school, collaborative learning, strategy, planning, elementary education. 


\section{PRIKAZI KNJIGA}

Objavljujemo jedan prikaz knjige koja je dala izniman doprinos odgoju i obrazovanju, a nije recentnija. Ostala tri prikaza novije su knjige iz područja kroatistike (dijalektologije), ranoga i predškolskoga odgoja i obrazovanja kao i o timskome radu. Vjerujemo da će pronaći put do onih osoba iz odgoja i obrazovanja koje na bilo koji način i na bilo kojoj razini odgoja i obrazovanja motiviraju učenike i studente (posebice buduće učitelje i učiteljice, nastavnike i nastavnice) u njihovom stjecanju pedagoških kompetencija.

\section{PRIKAZ KNJIGE}

Jerome Bruner (2000). Kultura obrazovanja.

Zagreb: Educa.

str. 229.

Autor, Jerome Seymour Bruner, američki psiholog, jedan od najdugovječnijih znanstvenika koji je dao značajan doprinos kognitivnoj psihologiji i teoriji učenja, tvrdi kako je mentalni život zapravo suživot. On se odvija uz pomoću kulturnih šifri i tradicije, a obrazovna praksa je najpogodniji teren za njegovo testiranje (Bruner 2000). Svoj put zaključivanja iznosi kroz devet poglavlja ove knjige.

U prvome poglavlju, Kultura, um i obrazovanje, autor smješta obrazovanje u širi kontekst potreban za njegovo razumijevanje. Premda je kultura čovjekovo djelo, ona oblikuje i omogućuje funkcioniranje ljudskoga uma. Učenje i mišljenje su smješteni u kulturnome okružju i uvijek ovise o utjecaju kulturnih resursa (Bruner 2000).

Kritizira „računalizam“ na primjeru tumačenja teksta. Značenje riječi ovisi o pretpostavljenom značenju čitavoga teksta, koji pak zavisi od značenja pojedinih riječi. Tražeći, danas 19 godina nakon nastanka ove knjige, usporedbu s kvantnom teorijom, mogli bismo ovu zavisnost značenja nazvati kontekstualna spregnutost. Taj put zaključivanja ukazuje na nemogućnost pred kojom se nalazi strojni, strogi programski pristup. Nije moguće istodobno dati više značenja jednomu nizu podataka. S druge strane ljudski je mozak u stanju izvesti višestruku i brzu redeskripciju, reprogramiranje značenja za neograničenni broj riječi unutar teksta uz stalno praćenje promjene značenja čitavoga sadržaja i brojnih pratećih aspekata. Računalo ne može imati bazu „kontekstikon“ svih mogućih tumačenja u kojima se određena riječ može naći. 
Na ovaj je način, prije gotovo dva desetljeća, autor najavio ograničenja koja će imati koncept umjetne inteligencije. Danas je čitava civilizacija, uglavnom bez općega pristanka, lansirana u prostor umjetne inteligencije, kvantnih računala, block chain tehnologije, čije su razvojne i aplikativne posljedice nepredvidive, a jedino im je zajednička ljudska spoznajno-organizacijska nespremnost i općenito nerazumijevanje.

Polazište drugoga koncepta, kulturalizma ukazuje na drugačiji pristup: obrazovanje nije otok, ono je dio kontinenta kulture. Kulturalizam gleda i makrorazinu kulture kao sustava od određenih elemenata te njezinu mikrorazinu, odnosno način na koji zahtjevi kulture utječu na one koji moraju u njoj funkcionirati. Pri takvome promatranju kulturalizam procjenjuje kako pojedinac konstruira stvarnost te kako stvara značenja koja mu služe da se toj stvarnosti prilagodi. Velika boljka kulturalizma je subjektivnost koja utječe na nastanak predodžbe te sposobnost da se vanjska, objektivna stvarnost spozna jedino mogućnostima uma i simboličkim sustavom na koji se um oslanja uvažavajući i emocije. Kultura osigurava resurse koji pomažu adaptaciji pojedinca i utječu na obrazovanje kroz nekoliko načelnih postavki: perspektivnosti, ograničenja, konstruktivizma, o interakciji, eksternalizacije, instrumentalizma, institucionalnosti, o identitetu i samopoštovanju, narativnosti.

U drugome poglavlju, Folk pedagogija, izlaganje počinje zagonetkom primjene teoretskoga znanja na praktične probleme. Kako naše znanje smjestiti u živi kontekst u kojem se problem pojavljuje? Pronalaženje optimalne veze između sadržaja nastavnoga programa, oblikovanje u probleme i primjereno povezivanje s iskustvom učenika, oduvijek je bio ključni zadatak za nastavnika. Uspješno rješavanje ovoga zadatka pokreće motivaciju i uvjetuje početak učenja. Pri tome je vrlo važno uspješno rješavanje problema predstavljanja sadržaja ili shvaćanje načina „kako ljudi razumiju ono što drugi hoće reći“. Prirodno su se oblikovale laičke, neeksplicitne i intuitivne teorije o ovome problemu razumijevanja drugih ljudi, koje nazivamo „folk psihologija“. Na jednak način je oblikovana i ,folk pedagogija" gdje odgajatelji svoju djecu nastoje poučiti uzimajući u obzor njihov stupanj kogntivnoga razvoja, iako svoje postupke i pedagoška načela možda ne bi znali verbalizirati. Vrlo je važno poznavati ovu važeću psihološko-pedagogijsku paradigmu kod namjere uvođenja novosti, jer su one već oblikovale praktične smjernice među kojima novost tek treba izboriti mjesto.

Istraživanja dječjega ponašanja pokazala su da djeca shvaćaju kako na „svijet“ ne djeluju neposredno nego posredovanjem uvjerenja što označava velik pomak u njihovu učenju i mišljenju. Tako je u istraživanjima sve veća uloga ne samo provjera egzaktnih znanja nego i stavova koje učenici imaju o tim znanjima. Po izricanju pitanja: što je znanje, odakle dolazi kako ga stječemo, autor daje tumačenje kako se 
čak i složenija znanja često svode na derivacijski jednostavnija znanja koja već posjedujemo. Nadalje razrađuje četiri modela učeničkoga uma i pedagoška modela.

Prvi je oponašanje, koji se oslanja na demonstraciju i karakterističan je za tradicionalna društva, a ne za razvijena. Drugi glasi da djeca uče u didaktički oblikovanim situacijama, a sposobnosti nisu zamišljene kao gotove strukture (verbalne, interpersonalne, numeričke itd.), djetetov um je pasivan, „posuda“ koja čeka da ju napunimo. Ovaj didaktički pristup promatra dijete izvana, iz perspektive treće osobe.

Djeca kao mislioci, predstavlja treći model koji govori o razvoju intersubjektivne razmjene i pokušaju uvažavanja djetetove perspektive u procesu učenja. Nastavnici žele shvatiti što djeca misle i kako do tih zaključaka dolaze. Djeca konstruiraju svoj model svijeta tijekom procesa tvorbe svoga iskustva, a pedagogija im pomaže da taj model bude potpuniji, manje plošan, više dimenzionalan i što dublji. Rasprava i suradnja su glavni instrumenti ovoga procesa čiji su rezultati sloboda izražavanja i razumijevanje.

Svi su ljudi sposobni intelektualno oblikovati ideje i uvjerenja kroz razgovor i interakciju odnosno razmjenu razumijevanja. Unutar ovoga modela razvila su se četiri pravca: djeca pokušavaju razviti sposobnost „čitanja tuđih misli“ ili istraživanje intersubjektivnosti koje počinje već od prvoga vizualnoga kontakta majke i novorođenčeta, drugi je pravac djetetovo razumijevanje tuđih ,intencionalnih stanja", treći je proučavanje metakognicije, onoga što misle o vlastitim kognitivnim operacijama, dok je četvrti pravac usmjeren na suradničko učenje i rješavanje problema te kako djeca ekspliciraju i revidiraju svoja uvjerenja odnosno kako shvaćaju i kako upravljaju vlastitim učenjem.

Četvrti pedagoški model, djeca željna znanja ili upravljanje „objektivnim“ znanjem. Kultura kao ni znanost nisu skloni naglim rekonstrukcijama nego promjenama sa suzdržanosšću jer se provjerena praksa ne uzima olako i stoga jer ih upravo čuva kao određenim oblikom kulturne inercije. Ovo kod djeteta vrlo rano počinje izazivati konflikt zbog razlika koje opaža u kulturi i drugoga svijeta, znanstvenih činjenica koje se razlikuju od postojećega kulturnog obrasca gdje bi nastava trebala djetetu pomoći u shvaćanju tih razlika. Tada dokazi trebaju poslužiti provjeri uvjerenja što je način izgradnje vlastitoga stava i pogleda na svijet.

Autor kroz pojam „stvarno školovanje“ ukazuje na kompleksnost obrazovnoga zadatka i njegovu višeobličnost dok je zadatak procesa zajednički: njegovati i razvijati umijeća i sposobnosti, prenijeti znanje o činjenicama i teorijama, produbljivati razumijevanje i uvjerenja, s time da treba shvatiti moć pedagogije kao medija koji nosi svoju poruku i ima ogroman utjecaj. Konačno, svoje promišljanje o umu, kulturama i obrazovanja autor postavlja kroz dvije dimenzije: internalistič- 
ko-eksternalistički, ,iznutra prema van“, gdje su eksternalističke usmjerene na ono što odrasli mogu učiniti za djecu kako bi potaknuli njihovo učenje, a internalističke na ono što dijete može samo učiniti u okviru svojih unutarnjih stanja kako bi pospješilo proces učenja, a druga opisuje stupanj intersubjektivnosti ili zajedničkoga razumijevanja. Moderna pedagogija ide prema stavu da bi dijete moralo biti sve više svjesno vlastitih procesa mišljenja i vlastite odgovornosti u tome procesu.

U trećem poglavlju, Složenost obrazovnih ciljeva, počinje se razmatrati pojavu antinomija - proturječja između dvaju načela ili dvaju zaključaka izvedenih iz podjednako vjerojatnih pretpostavki koje pronalazi već u ranome obrazovanju. Prva od navedenih jest ona da je funkcija obrazovanja omogućiti pojedincu razvoj sposobnosti i vještina koje će mu služiti u uspješnome životu u društvu i punom razvoju njegove individualnosti nasuprot onoj gdje je obrazovanje reprodukcija kulture i svih obrazaca upravo onoga društva koje ga podržava, što je u suprotnosti jedno s drugim. To su dva ideala s kojima se treba suočiti jer bi u suprotnome oba mogla ostati nedostignuta. Nadalje autor podsjeća na teoriju deprivacije koja govori o utjecaju koji okolina može svojom kvalitetom imati na razvoj pojedinca, odnosno posljedice koje ona nekvalitetna može imati u smislu smanjenih sposobnosti. Kultura posjeduje svoj ideal te se deprivacija mjeri u obliku i intenzitetu odstupanja od te referentne točke neke kulture ili njezinom idealiziranom standardu te se tako težilo reprodukciji društvenih modela vrijednosti. Ovaj model procjene kulturne deprivacije zapravo posredno okrivljuje žrtvu, žrtvinu majku i majčinu kulturu. Autor navodi probleme siromašnih i crnaca ili latino-amerikanaca i sudski spor, koji je pokrenuo i dobio gospodin Brown protiv školskoga odbora u gradu Topeka, Kanzas, SAD, zbog toga jer obližnja škola „samo za bijelce" nije dopuštala upis njegovoj kćeri, koja je zbog toga morala svakodnevno odlaziti u udaljeniju „školu za crnce“. Spor je završio pedesetih godina 20. st., a vrhovni sud je proglasio školsku rasnu segregaciju kao neustavnom.

Autor navodi projekt Head Start kao sveobuhvatni pokušaj da se siromašnim obiteljima pruži potpora u smislu što ranijega uključivanja djece u obrazovanje, njihovoga zdravlja i prehrane te utjecaja na roditeljsku skrb. Program je otpočeo 1965. te doživio nekoliko revizija i obuhvatio preko 22 milijuna djece, predstavlja jedan od najdužih programa s namjerom sustavnoga osnaživanja američkih građana. Program nije „čarobni napitak“, još uvijek su društvene opstrukcije velike, preko $30 \%$ crnaca od 16 do 25 godine završi u zatvoru, ali je zaključak aktera programa kako sve suprotnosti nije moguće konačno riješiti nego je cilj uvijek postizanje učinkovitoga suglasja suprotnih gledišta.

Ovdje se, zaključno, pažnja usmjerava na ponašanje i stavove nastavnika, prikazano kroz rezultate Boyerovih ${ }^{1}$ studija: učitelji - oni koji bi reforme trebali provo-

1 Ernest Leroy Boyer, 1928 - 1995., američki povjerenik za obrazovanje, predsjednik Carnegie fondacije 
diti su skeptični, reforme se pokreću iz administracije ili zakonodavstva i uglavnom se bave regulacijom, a manje obnovom, da učitelji u sve to uglavnom nisu uključeni, preko polovine anketiranih potvrđuje da je njihov radni elan gotovo nestao. U postizanju ciljeva obrazovanja treba ne samo preobraziti programe i školu u kulturu učenja nego i nastavnike, dajući im obnoviteljsku ulogu na svim razinama.

U poglavlju Poučavati sadašnjost, prošlost i moguće autor počinje razmatranje naglašavanjem intimne perspektive poučavanja i učenja u školi. Autor navodi djelo Ann Brown ${ }^{2}$ kao vrlo utjecajno, a ključnim za razumijevanje pojma učenja i poučavanja ističe: djelovanje - kao preuzimanje veće kontrole nad vlastitom mentalnom aktivnosti, refleksija - smisleno povezivanje i razumijevanje naučenoga, suradnja - razmjena resursa raznovrsnih pojedinaca te kultura - način života i razmišljanja koji konstruiramo, dogovaramo, institucionaliziramo te takav nazivamo „stvarnost“. Nadalje se iznosi odnos prirodnih kao „tvrdih“ i društvenih kao „mekih“ predmeta gledano kroz stavove učitelja te ulogu govornoga, narativnoga iskaza u procesu učenja, zaključujući kako je cilj djelovanja produbljivanje svijesti za što nam je potrebna raznovrsnost.

I kroz slijedeće poglavlje, Kako razumjeti i objasniti druge umove, u svome neprekidnom inzistiranju na važnosti uloge narativnoga iskaza, koji se provlači kroz sva razmatranja, autor usmjerava pozornost čitatelja prema razlici pojmova objašnjenje i interpretacija kao razlici u uzročno-eksplikatornome i interpretativno-hermeneutičkome pristupu u razumijevanju vlastitoga i tuđega mišljenja. Ova se dva pristupa razlikuju i imaju različite uloge u potrazi za znanjem. Općeprihvaćena istina koju nije potrebno dokazivati, truizam, je ona da razumijevanje ovisi o diskursu sugovornika. Tumačenje poruke ovisi u značajnoj mjeri i o uzajamnome stavu sugovornika, o bazi značenja izraza kojom raspolaže svaki od njih te sposobnosti opisivanja koju posjeduju sugovornici, tako su drevni kineski matematičari smatrali da se matematički problemi rješavaju retoričkom raspravom, a stari Grci da je važan deduktivni put, put zaključivanja. Ovdje autor rezimira izneseno na perspektivu, diskurs i kontekst kao ključne činitelje intersubjektivne razmjene. Kako pomiriti interpretaciju i objašnjenje? Ponašanje prema djetetu na način kao da znate što ima na umu ili kao da ono zna što je vama na umu utječe na razvoj njegove sposobnosti razumijevanja poruka iz okoline. Dodajući s vremenom sve

za unaprjeđivanje obrazovanja, koji je imao, kao jedan od svojih najvećih zadataka, doprinijeti razumijevanju između učitelja i administracije o metodama i programima koji se provode u školama. Autor je mnogih izviješća koja su dala drugo lice obrazovnom sustavu, posebno dok je bio predsjednik Carnagie fondacije.

2 Ann Leslie Brown, 1943. - 1999., američka školska psihologinja koja se bavila razvojem metoda učenja, strategija pamćenja, a zaslužna je za tvrdnju kako dječje poteškoće u učenju potiču iz nemogućnosti upotrebe metakognitivnih strategija. 
novija i različitija tumačenja gradimo kulturni diskurs djeteta. Bogatstvo ovoga koncentrata ovisit će o interaktivnim arenama nečije kulture, ili prema Bourdieu ${ }^{3}$ o „simboličkim tržištima“.

Autor u poglavlju Narativni iskazi prirodnih znanosti počinje od tvrdnje Roberta Karplusa ${ }^{4}$, kako je neznanje kronično stanje i učenika i znanstvenika. Znanost ne postoji u prirodi nego je oruđe uma onoga koji zna. Resursi su bitna pretpostavka da škola riješi brojne probleme, ali sami po sebi neće ih riješiti nego nam je potreban pokret koji će nam reći kamo smo se uputili i dati dublji osjećaj o tome kakvi ljudi želimo biti. Uobičajena je navika zapadnjačkoga načina mišljenja kako je svijet racionalan i da će objašnjenje o njemu uvijek biti u obliku objašnjivih i logičkih pretpostavki, iako na primjer fizičari priznaju kako je u fizici 95\% spekulacija, „fizička intuicija“, a $5 \%$ promatranje kao „ono nešto“ što pravi fizičari posjeduju i na temelju čega se znaju snalaziti u teorijama i bez mjerenja i promatranja stvarajući tako „spekulativne modele“.

Poglavlje Narativni konstrukt stvarnosti govori da postoje univerzalni pogledi, narativni iskazi koji su bitni za život u nekoj kulturi. Inteligencija nije „, glavi“ nego nešto „raspodijeljeno“ $u$ svijetu neke osobe, ona označava mikrokulturu prakse te „distribucijskoj mreži“ odnosno okruženju ljudi s kojima osoba radi i živi. Izgledi da dobijete Nobelovu nagradu se povećavaju ako radite s nekim tko ju je već dobio u prvome redu radi pristupa bogatoj distribucijskoj mreži koja stimulira. Nemoguće je razlikovati narativni opis od narativnoga diskursa, svaki daje oblik drugome, kao što mišljenje utječe na jezik i obratno. Nadalje, kao promišljanje i potvrdu, autor navodi devet univerzalnih obilježja narativne stvarnosti.

Osvještenje narativnoga prikaza postižemo kroz kontrast, konfrontaciju i metakogniciju. Golem pedagoški trud ulaže se u poučavanje metoda znanosti i racionalne misli umjesto da se posveti pozornost samomu nastajanju stvarnosti, o čemu govori narativni iskaz.

Autor u poglavlju Znanje kao djelovanje počinje razmatranje iz rasprave sa psihologinjom Scribner navodeći kao polazište svoje stereotipno shvaćanje psi-

3 Pierre Bourdieu, 1930. - 2002., francuski sociolog, antropolog, filozof, autor teorije socijalne stratifikacije zasnovane na estetskome testu, zatim podjelu društvenoga prostora na „polja“, teorija o medijima i kulturnoj produkciji i teorija praktičnoga djelovanja, samo su neka područja i Bourdieove teorije.

4 Robert Karplus, 1927. - 1990., teorijski fizičar, austrijanac, emigrant iz Beča, 1938. u Ameriku, student na Harwardu, istraživač na Prinstonu, predvodnik razvoja poučavanja prirodnih znanosti sukladno Piagetovoj teoriji kognitivnoga razvoja, zaslužan za prilagodbu znanstvenih sadržaja na elementarnu razinu, nakon opsežnoga, petnaestogodišnjega rada u Science Curriculum Improvement Study (SCIS), koji je prihvaćen kao temeljni, putpuno testiran priručnik zasnovan na laboratorijskim pokusima iz područja fizike i biologije. 
hologije rada kao saznanja o umoru i zadovoljstvu radnika, da bi kasnije uvažio kako je um produžetak ruku i oruđa kojima radimo i puno prije znamo što trebamo učiniti nego što smo to u stanju konceptualno objasniti, dakle aktivnost stvara prototip kulture. Načini na koje činimo odražavaju implicitne oblike pripadnosti kulturi.

Zaključno razmatranje, Sljedeće poglavlje psihologije, autor usmjerava na proučavanje čovjeka te izazov intersubjektivnosti uz shvaćanje kulture kao posredničkoga procesa u ljudskome reagiranju na svijet. Kultura počiva na sposobnosti čovjeka da shvati simboličke odnose te da su način na koji ljudi stvaraju značenje i o njemu se dogovaraju u središtu kulturnoga zaokreta. Kultura nameće ograničenja ljudskomu umu, dok je za razumijevanje važno uzeti u obzor biološki korijen ljudskoga djelovanja. Psihologija budućnosti mora uzimati u obzir suptilnu igru biologije i kulture.

U drugome dijelu završnoga razmatranja autor filogenetski i ontogenetski istražuje pojavu intersubjektivnosti ljudske vrste, dakle s aspekta postanka i značenja te tvrdi kako humanoidni kompleks um/mozak ne „iznikne“ biološki sukladno nekim genetski predodređenim rasporedom nego da on "procvate“ kada ga se njeguje u ljudskome okolišu pozivajući se na lingvističke nativiste (Chomsky ${ }^{5}$ i Fodor) i ukazjući na iznimnu ulogu jezika u općem razvoju ljudske vrste kroz razradu „mreže uzajamnih očekivanja“ kao matrice konstrukcije kulture.

Kao zaključak navodimo da je promjena kulture, kroz istraživanja i skupno djelovanje svih činitelja, uvjet za kvalitetu i uspjeh promjena u odgoju i obrazovanju. Iako ne postoji opća definicija kulture, podrazumijeva sve aspekte interaktivnosti sudionika toga konteksta te njezinu povijest, vrijednosti, norme, kolegijalnost, stavove i odnose koje dijele svi koji utječu na odgojno-obrazovni proces.

Bruner (2000) pod školskom kulturom podrazumijeva „stvaranje zajednice učećih subjekata koji si uzajamno pomažu“ te navodi kako „ono što škola poučava, načini mišljenja i 'govorni registri' koje njeguje kod svojih učenika, ne mogu se izolirati od uloge koju ima u životima i kulturi svojih učenika“. Brunerova središnja teza je da „kultura oblikuje um, osigurava oruđe kojim konstruiramo, ne samo naše svjetove, već i razvijamo samokoncepciju, te spoznajemo vlastite sposobnosti“, što znači „da su učenje i mišljenje uvijek smješteni u neko kulturno okružje“.

Marijan Madunić

5 Američki lingvist, filozof, profesor emeritus na MIT-u, „otac moderne lingvistike“. 


\section{PRIKAZ KNJIGE}

\section{Lina Pliško i David Mandić (2019). Govori općine Marčana.}

Pula: Sveučilište Jurja Dobrile u Puli.

str. 416.

\section{U spomen našim predcima i u nasljeđe potomcima}

Godine 2019. svjetlo dana ugledala je još jedna dijalektološka knjiga Line Pliško i Davida Mandića. Nakon zajedničkoga prvijenca Govori općine Ližnjan ovaj se autorski dvojac hrabro uputio u izradu novoga djela o istarskim govorima. Knjiga Govori općine Marčana obuhvaća dvadeset i tri opisa govora, a nastala je u sklopu projekta Dijalektološka i jezičnopovijesna istraživanja hrvatskoga jezika Hrvatske zaklade za znanost, voditelja prof. dr. sc. Josipa Lisca. Govori se odnose na sljedeća naselja: Belavići, Bratulići, Cokuni, Cetinići, Divšići, Filipana, Hreljići, Kavran, Krnica, Kujići, Loborika, Mali Vareški, Marčana, Mutvoran, Orbanići, Pavićini, Peruški, Pinezići, Prodol, Rakalj, Šarići, Šegotići i Veliki Vareški.

Lina Pliško i David Mandić su objasnili da je ovo djelo rezultat istraživanja koja su započela prije dvadesetak godina te da su im u tome uvelike pomogli i njihovi studenti terenskim istraživanjima vlastitih i(li) susjednih idioma. Veliku zahvalu uputili su i brojnim informantima koji su „strpljivo odgovarali“ i prisjećali se raznih događaja iz vlastita života i mjesta. Tužnu konstataciju iz Proslova kako svjedoče o velikim promjenama i polaganim nestajanjem nekih govora svakako možemo gledati s malo više nade držeći u ruci djelo koje s brojnim zabilježenim idiomima ostaje kao svojevrsna vremenska kapsula i za sljedeće generacije.

Knjiga je podijeljena u sedam temeljnih poglavlja. Prvo poglavlje, Geografski, demografski i povijesni podaci općine Marčana uvodi nas u zemljopisne i etnografsko-statističke podatke o ovoj Općini, koja „na sjeveru graniči s Općinom Barban, na sjeverozapadu s Općinom Svetvinčenat, na zapadu s Gradom Vodnjanom, na jugozapadu s Gradom Pula, a na jugu s Općinom Ližnjan“. Statistički podatci zorno ukazuju na broj i spol stanovnika te njegove mijene i podjele po jezicima za pojedina mjesta od davne 1850. godine do naših dana. Neka naselja, kako saznajemo iz nastavka, sežu čak u prapovijesno doba.

Poglavlje Marčanski govori u dosadašnjim istraživanjima temeljito navodi sva dosadašnja istraživanja ovih područja. Među istraživačima ovih prostora možemo tako pronaći Josipa Ribarića, Mieczysława Małeckoga, Radoslava Boškovića, Matu Hraste, Petra Šimunovića, Ivu Lukežić, Rudolfa Ujčića, Stjepana Vukušića, Katarinu Matanović, Samantu Paronić, Romanu Percan, Josipa Lisca, Miru Menac Mihalić, Anitu Celinić i, dakako, autore - Linu Pliško i Davida Mandića. 
U sljedećemu poglavlju, Načela istraživanja, autori ukazuju na način i metodologiju svojega rada. Istraživanja su provodili ispunjavanjem Upitnika za istraživanje jugozapadnoistarskih govora i snimanjem izvornih govornika. Dodaju detaljnu tablicu istraživača i obavjesnika po naseljima, ali zbog Zakona o zaštiti podataka, obavjesnicima su navedeni samo inicijali i godine rođenja. Poglavlje zaokružuju dvije zemljopisne karte na kojima se može vidjeti položaj Općine Marčana u Istarskoj županiji te mjesta s opisanim govorima u Općini Marčana.

Slijedi četvrto i ključno poglavlje ove knjige, Govori općine Marčana, podijeljeno na tri potpoglavlja: Glasovi, Akcentuacija i Morfologija, unutar kojih nalazimo i brojne manje cjeline. Kod opisa glasova imamo detaljne opise samoglasničkoga i suglasničkoga sustava, s ključnim odlikama govora ovih mjesta i brojnim potvrdama s terena. Možemo tako saznati o odrazima jata, prednjega i stražnjega nazala, jerova, slogotvornoga $l$, raznim promjenama i specifičnim glasovnim skupovima karakterističnih u govorima općine Marčana. Kod naglasnoga sustava najprije je opisan inventar i distribucija s obilježjima, poput zanaglasne dužine, akuta, neoakuta i različitih vrsta povlačenja naglaska, a potom tri temeljna naglasna tipa te miješani naglasni tipovi. Opis morfološkoga sustava započinje imenicama, nakon čega su opisani pridjevi, zamjenice i glagoli.

Peto je poglavlje Zaključak, u kojemu autori potvrđuju tezu o pripadnosti „marčanskih govora jugozapadnome istarskome dijalektu prema klasifikacijama Dalibora Brozovića (1988.) i Josipa Lisca (2009.)“ te napominju da su im snimljeni govori ukazali i na naglasne osobine, koje nisu bile predviđene upitnikom. Ovdje se ukratko odgovara i na pitanje kompaktnosti marčanskih govora. Autori su zaključili da su marčanski govori uglavnom kompaktni na fonološkoj i morfološkoj jezičnoj razini, što znači da se bitna razlika može pronaći u naglasnome sustavu govora Loborike, Raklja i proštinskih sela, dok se na morfološkoj razini jedino govor Kavrana razlikuje po svojim nastavcima za dativ, lokativ i instrumental množine. Prema tim značajkama Pliško i Mandić predlažu dvije podskupine marčanskih mjesnih govora: „sjeverozapadnu“ i ,jugoistočnu“. Prvoj skupini pripadaju tako naselja: Belavići, Bratulići, Cetinići, Divšići, Filipana, Hreljići, Krnica, Kujići, Marčana, Orbanići, Pinezići, Prodol i Šarići, a drugoj: Cokuni, Kavran, Loborika, Mali i Veliki Vareški, Mutvoran, Pavićini, Peruški, Rakalj i Šegotići. U nastavku je priložena i dijalekatska karta općine Marčana, na kojoj je lako uočljiva granica ovih podskupina. Na kraju se poglavlja marčanski govori uspoređuju sa susjednim govorima, i to: $s$ južnom podskupinom barbanskih govora (koju čine govori naselja: Manjadvorci, Rebići, Hrboki, Borinići i Škitača), te s govorima Valture, Muntića, Kacane i Svetvinčenta.

Nakon zaključnih razmatranja slijedi bogata Bibliografija i, po mnogima je- 
dan od najvrjednijih dijelova - Ogledi govora na čak 130 stranica. Ovi se ogledi govora mogu usporediti s fosilima u arheologiji, ostaju kao trajan dokaz te odraz vremena i mjesta u/na kojemu su napravljeni za buduće generacije.

Knjigu zatvaraju Bilješke o autorima, a uljepšavaju je stare fotografije ljudi s marčanskih prostora koje nam dočaravaju i tradicijske elemente i događaje. Imenovanjem tih ljudi fotografije dobivaju i važniju ulogu, sjećanja na stvarne osobe, koje uz ogledne primjere govora djelo čine zanimljivim i nestručnome dijelu čitatelja. Stoga, iako je djelo prvenstveno namijenjeno znanstvenoj zajednici i tako je koncipirano te je u tome smislu vrlo vrijedno, znanstvenici i studenti ne ostaju jedini koji će otvoriti ovu knjigu. Vjerujemo da će je mnogi mještani istraživanih krajeva s radošću (pro)čitati, barem neke dijelove i zanimljive činjenice o svojim i/ li susjednim/poznatim govorima. Time se širi vrijednost ovoga djela.

Autori su knjigu posvetili svojim bakama i djedovima, nabrojivši ih ponaosob, dajući time jedinstven pečat ovakvome djelu, napravljenomu u spomen predcima, ali koje ostaje kao nasljeđe potomcima.

Vanessa Vitković Marčeta 


\section{PRIKAZ KNJIGE}

Edita Slunjski i suradnici (2019). Izvan okvira 4, Mudrost vođenja: prikaz istraživanja i alati razvoja prakse vođenja

Zagreb: Element.

str. 256

Brojnim čitateljima Edite Slunjski poznat je njezin stil pisanja koji prije svega obilježava nastojanje da poveže teoriju i praksu, da zadovolji zahtjeve znanosti, ali da djelo bude jasno i korisno praktičarima te da ih potiče na promišljanje svoje prakse. U posljednjih pet godina izdala je tetralogiju znanstveno stručnih knjiga objedinjenih pod nazivom Izvan okvira. Iako je Programsko usmjerenje odgoja i obrazovanja predškolske djece iz 1991. godine dalo otvorena vrata svim vrtićima da ,izađu iz okvira“, Nacionalni kurikulum iz 2015. godine to je još jače naglasio, mnogi su praktičari nastavili s tradicionalnim praksama. Autorica duboko vjeruje, i svojim knjigama dokazuje, da je kvalitetu moguće mijenjati samo iznutra, da slova na papiru nemaju veliku vrijednost bez djelovanja.

Ovom knjigom, četvrtom „izvanokvirnom“, potvrđuje ideju da je za osiguravanje visoke kvalitete obrazovanja djece nužno kvalitetno vođenje ustanove i u ustanovi. Vođenje podrazumijeva utjecaj pojedinca na grupe s ciljem ostvarivanja ciljeva koji bi u idealnim uvjetima trebali biti zajednički svim uključenima. U odgojno-obrazovnome istraživačkom prostoru to je vrlo istraživan fenomen, kako u svijetu tako i kod nas. Ono što nedostaje u hrvatskome istraživačkom prostoru jest vođenje ustanova (i u ustanovama) za rani i predškolski odgoj i obrazovanje ${ }^{6}$ koje se po strukturi i načinu upravljanja razlikuju od ostalih dijelova sustava u nekoliko segmenata, a u odgojno-obrazovnome radu imaju brojne specifičnosti zbog čega ih je teško uspoređivati s ostalim dijelovima sustava. Edita Slunjski je, sa suradnicima, pokušala popuniti i ovu rupu u hrvatskome istraživačkom prostoru. Suvremene teorijske koncepte vođenja najprije je razradila u znanstvenoj monografiji „Izvan okvira 3, Vođenje: Prema kulturi promjene“ (2018) što pruža temelj četverogodišnjega akcijskog istraživanja koje je autorica provodila u vrtićima s područja Grada Zagreba, Zagrebačke županije, Sisačko-moslavačke, Karlovačke, Koprivničko-križevačke, Virovitičko-podravske i Zadarske županije, a koje čini okosnicu ove monografije.

Knjiga je podijeljena u 3 poglavlja. Započinje poglavljem pod nazivom Istraživanje procesa vođenja u vrtiću u kojem autorica definira polazište, značajke, sudionike te rezultate istraživanja koje zaključuje raspravom o vođenju s obzirom na

6 U daljnjem tekstu koristit će se skraćenica „rani odgoj“ ili „vrtić“ umjesto „rani i predškolski odgoj i obrazovanje“ 
specifične kontekstualne uvjete vrtića, na specifična umijeća vođe te na specifičnost vođenja s obzirom na različite strukture grupe. Autorica polazi od ideje da na kvalitetu odgojno-obrazovne ustanove uvelike utječe vođenje same ustanove što su potvrdili mnogi autori, a poziva se i na naš Nacionalni kurikulum za rani i predškolski odgoj i obrazovanje (2015) u kojem je vođenje vrtića i u vrtiću važan kontekstualni čimbenik kulture vrtića (uz prostorno materijalno i socijalno okruženje). Okosnicu istraživanja čini ideja zajedničke izgradnje razumijevanja i suradničke kulture. Mnogi bi pomislili da je tu kraj knjige, ali je autorica u ovoj knjizi, kao i u nekim prethodnima, dala prostor praktičarima, odgajateljima, pedagozima i ravnateljima ustanova ranoga odgoja da izraze svoje viđenje raznih tema vezanih uz vođenje polazeći od teze da je vođenje zajednički proces učenja.

U drugome poglavlju pod nazivom Pedagoško vođenje i izgradnja kapaciteta ustanova iz perspektive pedagoga sedam pedagoginja (Vesna Kašuba, Mirjana Slamar, Jasmina Knežević, Biljana Vidačić Maraš, Nikolina Bilogorević, Iva Debeljak i Anita Malašić) nekoliko javnih i privatnih vrtića predstavile su istraživanje u kojem su aktivno sudjelovale kao članice umrežene profesionalne zajednice učenja predškolskih pedagoga pod vodstvom prof. dr. sc. Edite Slunjski i prof. dr. sc. Ante Kolaka (Filozofski fakultet u Zagrebu - Odsjek za pedagogiju) na kojima su raspravljali o različitim aspektima vođenja s posebnim naglaskom na pedagoškoj i distribuiranoj dimenziji. Vrijednost ovoga poglavlja jest prvenstveno u tome što se bavi ulogom pedagoga u ustanovi ranoga odgoja koja je nedovoljno definirana te u domaćoj i stranoj literaturi gotovo potpuno zanemarena. Vođenje iz perspektive pedagoga podrazumijeva vođenje odgajatelja ka unapređenju odgojno-obrazovnoga procesa. Autorice poglavlja podijelile su svoje viđenje, dileme i probleme s kojima se svakodnevno susreću trudeći se ispunjavati svoju ulogu pedagoškoga vođe ustanove. Počevši od toga da je najvažnije poznavati i razumjeti kompleksnost i dinamiku odgojno-obrazovne prakse i kontekstualnih čimbenika ustanove u kojoj djeluju i koji uvelike utječu na vođenje, autorice zaključuju da pedagog svoju kompetenciju mora graditi na poznavanju teorije ranoga i predškolskoga odgoja i obrazovanja. Osim temeljnih znanja predškolske pedagogije, pedagozi svoje djelovanje moraju temeljiti na sofisticiranome poznavanju mikrokonteksta i kulture ustanove u kojoj rade (međusobnih odnosa među djelatnicima, načinu komunikacije, načinu vođenja) te istraživati načine njezina unapređenja. Najveća se prednost pritom pridaje profesionalnim raspravama koje moderira i vodi pedagog, a zahtijevaju istančane vještine facilitiranja, stvaranja poticajne klime u kojoj svi imaju pravo na vlastito mišljenje, davanja povratne informacije i koje se temelje na uzajamnome povjerenju i uvažavanju. Temeljna uloga pedagoga u ustanovi ra- 
noga odgoja je unapređenje odgojno-obrazovnog procesa $^{7}$, a to je bez kvalitetnoga vođenja nemoguće postići. Također, ono što su pedagozi izdvojili kao važno pitanje nakon postizanja neke promjene jest kako tu promjenu održati, kako održavati i razvijati kvalitetu rada ustanove jer se ponekad „zakovitla kolo“ promjene, ali onda ne samo da stane, već zna krenuti i unatrag.

U trećem poglavlju, pod nazivom Primjeri iz prakse i alati razvoja prakse vodenja, autorica nudi jedan zanimljiv format koji se sastoji od „zrnca mudrosti“ eminentnih autora o raznim aspektima vođenja, detaljnije razrade specifičnoga problema vođenja s prednostima i nedostatcima (npr. Prokletstvo brzih rješenja, Kultura preuzimanja rizika i priznavanja pogreške, „Klimava“ motivacija...), nakon čega slijedi još detaljnija „uputa“ za ravnatelje, pedagoge i odgajatelje, refleksije iz prakse brojnih praktičara te upitnici za samoprocjenu (za svaku profesiju posebno).

Posljednjim poglavljem autorica zaista daje konkretne alate koji mogu biti od velike pomoći praktičarima kako bi kroz promišljanje svoje voditeljske uloge unapređivali svoju praksu i utjecali na kvalitetu rada i kulturu cijele ustanove i šire.

Umjesto zaključka, autorica na kraju monografije nudi „zrnca mudrosti“ proizišla iz ovoga istraživanja, iz profesionalnih promišljanja ravnatelja, pedagoga, odgajatelja, same autorice te pisca predgovora, poznatoga hrvatsko-njemačkog znanstvenika Ivana Đikića koji i u predgovoru kaže da: „Djeca i mladi koji vole učiti, koji se usude misliti i koji su spremni surađivati kako bi stvarnost mijenjali na bolje, najvažniji su, a možda i jedini ključ razvoja kvalitetnijeg društva“ želeći reći kako ove vrijednosti treba razvijati od najranije dobi djeteta za što je nužno da ih odrasli i sami primjenjuju.

Možda bi joj neki zamjerili nedostatnu znanstveno-metodološku utemeljenost, no ono što autorici i ovoj knjizi nitko ne može zamjeriti jest kontinuiran, sustavan rad na unapređenju prakse ranoga odgoja, povezivanje teorije i prakse, poticanje praktičara na angažman, na istraživanje, reflektiranje i unapređivanje svoje profesionalne uloge. Edita Slunjski je i ovom knjigom, kao i mnogim prethodnima, dala veliki doprinos teoriji i praksi ranoga i predškolskoga odgoja i obrazovanja.

Doris Velan

7 Državni pedagoški standard predškolskog odgoja i naobrazbe, 2008 


\section{PRIKAZ KNJIGE}

\section{Tea Golja, Marlena Plavšić, Iva Slivar (2019). Collaborative learning guidelines.}

Pula: Sveučilište Jurja Dobrile u Puli.

str. 104.

Knjiga Collaborative learning guidelines (Smjernice za suradničko učenje): From Learners to Prosumers. Application in Organisations. Adults Collaborative Learning Within the ECORL Project nastala je u sklopu projekta ECORL (Economy Co-Responsability Learning). Izdavač knjige je Sveučilište Jurja Dobrile u Puli. Napisana je na engleskome jeziku. Autorice su profesorice ekonomije i psihologije na Sveučilištu Jurja Dobrile u Puli, i to na Fakultetu za interdisciplinarne, talijanske i kulturološke studije (izv. prof. dr. sc. Tea Golja), na Filozofskome fakultetu (doc. dr. sc. Marlena Plavšić), na Fakultetu ekonomije i turizma Dr. Mijo Mirković (doc. dr. sc. Iva Slivar).

Knjiga Collaborative learning guidelines (Smjernice za suradničko učenje) sadrži 104 stranice. Podijeljena je u četiri poglavlja i zaključak, a na samome kraju knjige je prilog i literatura kojom su se autorice koristile za istraživanje spoznaja o suradničkome učenju.

Prvo poglavlje naslova Collaborative learning and adult learning (Suradničko učenje i učenje odraslih) ima pet potpoglavlja: Learning theories (Teorije učenja), Collaborative learning (Suradničko učenje), Learning context (Kontekst učenja), Learning and technologies (Učenje i tehnologije) i Motivation for collaborative learning (Motivacija za suradničko učenje).

Prvo potpoglavlje Learning theories (Teorije učenja) donosi važne informacije o teorijama učenja od 1900. godine do danas, ali i renomiranim znanstvenicima bez kojih ne bismo mogli govoriti o učenju kao znanstvenomu psihologijskom predmetu proučavanja. Autorice tako spominju Watsona, Pavlova i Skinnera kao važne predstavnike biheviorizma, opisuju kognitivizam te nastavljaju s Bandurom koji naglašava važnost učenja u socijalnome kontekstu. Navode i Brunera te potvrđuju kako je švicarski razvojni psiholog Piaget bio jedan od prethodnika konstruktivizma, dok Vygotsky temelji svoje teorije na tome da ljudska bića usvajaju znanje počevši od odnosa s drugima i okruženja.

U drugome potpoglavlju Collaborative learning (Suradničko učenje) opisuje se važnost suradničkoga učenja koje se primjenjuje od aktivnosti u dječjem vrtiću i u obitelji te se razvija u raznim drugim djelatnostima tijekom života i rada osobe. Suradnički rad određuje se kao otvoreni proces, u kojemu je cilj voditi se pregovorima između članova grupe umjesto unaprijed definiranim metodama i pravilima. 
U tome se ogleda i odgovornost članova za učinjeno. Suradničko učenje determinira međusobna ovisnost članova grupe, podjela zadataka i upravljanje procesima grupe te cilj izgrađivanja nečega novog.

Sam kontekst učenja Learning context (Kontekst učenja), treće potpoglavlje autorice predstavljaju kao proces u kojemu pojedinac uči interakcijom s tri glavna područja: samim sobom, vanjskim okruženjem i društvenim kontekstom, te opisuju kako u određenoj situaciji učenja može prevladati jedno područje nad drugim. Interakcija s drugima najčešća je, a to je rezultat društvenoga konteksta. Navodi se da postoji 'učenje od drugih' i 'učenje s drugima'. Učenje, potvrđuje se i opisuje u ovoj knjizi, može biti formalno, informalno i neformalno. Dodaju da je u nekim zemljama obrazovanje odraslih sadržano u neformalnom obrazovanju, dok je u drugima to još uvijek formalno.

Četvrto potpoglavlje Learning and technologies (Učenje i tehnologije) naglašava da se teorije učenja odnose na učenje kao relativno trajnu promjenu motoričkoga, kognitivnoga i psihodinamičkoga ponašanja koja se javlja kao izravni rezultat iskustva. Autorice opisuju da neki od primjera tehnologija primijenjenih s kognitivnim pristupom mogu biti simulacije i multimedija. Digitalni sadržaji, svjedoci smo, danas se sve više uključuju u učenje djece i mladih koji na vrlo jednostavan način, potpomognuti digitalnom tehnologijom, upoznaju svijet informacija, postupaka i strategija, a da knjigu nisu ni uzeli u ruke. Ovi načini učenja imaju svoje pozitivne i negativne strane koje se svakim danom mijenjaju i nadopunjuju da bi doveli do toga da je svaka informacija od jučer već prestara i da se uvijek traži recentnija, novija. Primjerice, simulacije su kompatibilne s kognitivnom teorijom učenja jer predstavljaju formalizirane modele i izazivaju specifične kognitivne procese poput kreiranja i testiranja hipoteza. Danas se koristi 'podijeljeno učenje' (shared learning) koje omogućuje učenicima uključivanje u raspravu, preuzimanje odgovornosti za vlastito učenje, razjašnjavanje i procjenu ideje te na taj način razvijanje kritičkoga mišljenja. U tome kontekstu sociokonstruktivizam objašnjava da na ljudsku aktivnost utječu okolina i osobe koje u njoj djeluju, a prema Winnu (2002) tehnologija nikad ne može biti dovoljan uvjet za stvaranje zajednica u učenju. Informacijsko-komunikacijska tehnologija (ICT - Information Communication Technologies) sve više postaje način komuniciranja i suradnje među osobama, a virtualno okruženje nudi djeci i mladima mogućnost stvaranja konteksta u kojima je pristup informacijama sve dostupniji. Online učenje nudi većina odgojno-obrazovnih institucija te se znanje stječe i prakticira radi razvijanja vještina i oblikovanja stavova u stvarnim uvjetima. U knjizi se navode i opisuju mrežni komunikacijski alati integrirani u dizajn suradničkoga iskustva, kao što su: e-pošta i popis poštanskih adresa, grupe za informiranje, forumi za razgovore, wikis kao 
posebne mrežne stranice koje omogućuju svim korisnicima izmjenu svake stranice ne koristeći standardni HTML, QઐA usluge kao svojevrsni forumi za diskusiju organiziranim pitanjima i odgovorima, chat kao alati kojima osobe razgovaraju u realnome vremenu, grupe društvenih mreža (Social Networks Groups), videokonferencije kojima se osoba može koristiti putem Skypea ili Googlea (Hangout), virtualni svjetovi koji omogućuju osobama osjećaj da su u trodimenzionalnome svijetu te grupe s kratkim porukama.

Posljednje, peto potpoglavlje u prvome poglavlju knjige pod nazivom Motivation for collaborative learning (Motivacija za suradničko učenje) podijeljeno je u dva potpoglavlja Factors that enhance motivation (Čimbenici koji povećavaju motivaciju) i Challenges in collaborative learning (Izazovi suradničkoga učenja). Autorice naglašavaju važnost suradničkoga učenja za pojedinca, opisuju koliko ga pojedinci više žele od klasičnih oblika učenja. Vrijednost takvoga oblika učenja je i u tome što članovi grupe kroz interakciju mogu rekonstruirati svoje ideje i oblikovati neko novo razumijevanje koje inače ne bi mogli sami otkriti. Spominje se i suradničko online učenje kojim su ishodi učenja dostupniji. Učinkovite strategije ovoga oblika učenja uključuju: kreiranje scenarija igranja uloga za određivanje i vođenje interaktivnih interakcija, uspostavljanje i pridržavanje pravila i postupaka razmjene među studentima i pružanje razrađenih, relevantnih i pravovremenih povratnih informacija i od nastavnika i od vršnjaka (prema Borokhovski i sur., 2012). Jedna od konstruktivističkih strategija usmjerena na uključivanje učenika u zajedničko učenje je učenje temeljeno na problemima. Izazovi suradničkoga učenja mogu predstavljati mnogobrojne poteškoće i primjedbe o sudjelovanju ili nesudjelovanju, kao npr. previše se vremena gubi za objašnjenje materijala ostalim članovima grupe, dominira samo jedan ili samo nekoliko članova grupe, sudionici se suzdržavaju od izricanja ideja zbog straha od negativne ocjene drugih članova te fokus je samo na kognitivnoj dimenziji zadatka, dok je socijalna dimenzija zanemarena. Za svaku primjedbu autorice su opisale komentar i moguće rješenje. Također, autorice ističu važnost osobnoga iskustva u suradničkome učenju.

Drugo poglavlje Open educational resources (OERs) (Otvoreni odgojno-obrazovni izvori) detaljnije opisuje sve studije slučaja partnera uključenih u ECORL projekt i objašnjenje na temelju iskustava svakoga partnera. Vidljive su razlike u pristupu, realizaciji, korištenim metodologijama i reakcijama, odnosno povratnim informacijama. Ti se primjeri mogu smatrati vrijednim prinosom za donošenje zaključaka o mogućim metodama organiziranja sličnoga projekta na drugim mjestima u Europi i svijetu.

Obrazovanje odraslih susreće se s izazovima kao što su: stvaranje interaktivnih okruženja za učenje uživo poput susreta i razmjene mjesta znanja među uče- 
nicima, učiteljima i svjedocima te pružanje produbljivanja obrađenih tema, dostupnih u bilo koje vrijeme na mrežnim stranicama, otvoreno i besplatno, kao što je mrežni digitalni sadržaj. Projekt ECORL zadovoljava ove potrebe u eksperimentu kombiniranih aktivnosti s prilagođenim načinom obuke ostvarenim u svakoj zemlji konzorcija i stvaranjem više od 50 otvorenih odgojno-obrazovnih resursa o dijeljenju ekonomije, etičkim financijama, socijalnome poslovanju, poduzetništvu, održivome načinu života, društvenim odgovornostima poduzeća i ostalim relevantnim temama. Ti otvoreni odgojno-obrazovni sadržaji predstavljaju skladište ECORL mrežnih stranica, virtualno okruženje u kojemu je moguće učiti i ažurirati kompetencije odraslih zahvaljujući videoprezentacijama, PPT-ovima, mrežnim izvorima, tekstovima i vježbama. Ponuđeni predložak rezultat je metodologije testirane na odraslima iz više europskih zemalja. Otvoreni odgojno-obrazovni izvori su dvojezični radi pružanja sadržaja na materinjem i na engleskome jeziku. Opisuje se da učenici (odrasli) trebaju testirati svoje opće kompetencije u socijalnoj ekonomiji mrežnim anketama kako bi odabrali najprikladniju internetsku aktivnost.

Treće poglavlje The ECORL consortium case studies (Studije slučaja u konzorciju ECORL) nudi primjere pet zemalja koje na različite načine organiziraju obrazovanje odraslih. Autorice počinju s Albanijom koja je kroz Yunus social business Balkans razvila eksperimentalni program u kojemu su polaznici morali simulirati scenarije iz stvarnoga života u odnosu na cilj učenja: povećati kapacitete polaznika za stjecanje neovisnih prihoda kako bi se podržale službe zapošljavanja marginaliziranih mladih. Republika Hrvatska predstavljena je u ovoj knjizi kroz aktivnosti Pučkoga otvorenog učilišta Pula. Dvije grupe polaznika pohađale su satove socijalne ekonomije u dvije godine projekta. Cilj je bio steći znanja o društveno-odgovornome poslovanju i ekonomiji dijeljenja. Ostvaren je, među ostalim, pozitivan društveni utjecaj kroz poduzetništvo. Cilj projekta u Italiji kroz Università popolare di Firenze bio je odgovaranje na potrebe ekonomske pismenosti, što odraslima posebno nedostaje jer je ekonomska kriza utjecala na mlade i odrasle u svim društvenim područjima. Suradničko učenje u suradnji sa zajedničkim projektima socijalnoga poslovanja, na primjeru ove zemlje, može se smatrati inovativnim i kreativnim modelom učenja odraslih. Litva putem EU Trade-a razvija prilično opsežan koncept suradničkoga učenja. Uzorak istraživanja u ovoj zemlji sastojao se od odraslih studenata i studentica preddiplomskoga studija različitoga kulturnog i profesionalnog podrijetla kojima je cilj bio učiti o društveno-odgovornome poslovanju i ekonomiji dijeljenja. Projekt u Španjolskoj imao je tri glavna utjecaja temeljena na biheviorističkoj, kognitivističkoj i konstruktivističkoj teoriji. Nakon ekonomske krize, koja je rezultirala visokom stopom nezaposlenosti i nedostatkom poznavanja ekonomije u španjolskome društvu, aktivnosti iz ovoga projekta 
popunile su prazninu među kompetencijama osoba. Učili su o socijalnoj ekonomiji, a alternativni metodološki pristupi koji su se koristili motivirali su učenike i dokazali da obrazovanje odraslih može biti korisno, zanimljivo i osnažujuće. Autorice završavaju ovo poglavlje ishodima učenja koje će dostići osoba koja prolazi kroz aktivnosti iz projekta opisane na primjerima različitih zemalja. Ukupno je kroz projekt prošlo 130 osoba.

$\mathrm{U}$ četvrtome se poglavlju pod naslovom Collaborative learning in organisations (Suradničko učenje u organizacijama) opisuje da je bilo vrijedno istražiti kako se koncept i načela suradničkoga učenja mogu koristiti u poslovanju u konceptu organizacije koja uči. Stoga, u ovome se poglavlju predstavlja praktična primjena suradničkoga učenja. Autorice ističu da iako se proces nije odvijao u poslovnome okruženju, već u okviru dva sveučilišna kolegija, zadatak je bio pravi poslovni izazov. Cilj je ovoga poglavlja, na temelju primjera, pružiti vodič za primjenu suradničkoga učenja u različitim organizacijama. U primjeru s Fakulteta za interdisciplinarne, talijanske i kulturološke studije Sveučilišta Jurja Dobrile u Puli, kroz planiranje, implementaciju i vrednovanje, opisuje se studija slučaja - stvaranje novoga hotelskoga brenda.

Autorice na kraju knjige zaključuju da je tehnika suradničkoga učenja prikladna za suvremenije teme $u$ različitim aktivnostima rješavanja problema u organizacijama, dobra je smjernica za razvoj organizacija te se u praksi prilično često koristi. Ističu da je važno na odgovarajući način razmijeniti znanje i primijeniti ga u poslovnoj praksi. Suradničko učenje u poslovanju dovodi do stvaranja novih znanja, ali i izazova, a njegova primjena u školskome sustavu dovodi do otkrivanja novih znanja za timove.

Fotografije koje prate sadržaj u knjizi Collaborative learning guidelines (Smjernice za suradničko učenje) ukazuju na vjerodostojnost aktivnosti koje su provedene u sklopu projekta u različitim zemljama. Prilog je vezan uz istraživanje u primjeru iz četvrtoga poglavlja, primjeru s Fakulteta za interdisciplinarne, talijanske i kulturološke studije Sveučilišta Jurja Dobrile u Puli.

Korištena su 42 izvora (knjige, članci i mrežni izvori) literature koji ukazuju na raznovrsnost $\mathrm{i}$ interdisciplinarnost teme koja je povezana sa psihologijom, zadire u područje pedagogije i didaktike, ali na jedan poseban način korelira s ekonomskim istraživanjima i društvenim pitanjima te ukazuje na još veću povezanost suradničkoga učenja i rada u organizacijama.

Ova je knjiga namijenjena studentima različitih smjerova, učiteljima, nastavnicima, pedagozima i ekonomistima te ostalim znanstvenicima, stručnjacima i praktičarima koji usmjeravaju djecu i mlade u suradničko učenje koje je, posebice danas, izuzetno cijenjeno u radnim organizacijama koje povezuju djecu i mlade s 
tržištem rada. Namijenjena je i stručnjacima koji se bave socijalnom ekonomijom, psihologijom, pedagogijom i metodologijom istraživanja jer ukazuje na važnost suradničkoga učenja i na elemente koje treba uključiti u istraživanje ovoga vrijednoga društvenog kapitala.

Marina Diković 
